\title{
Sourcing from Africa: a systematic review and a research agenda
}

\section{Summary}

The African continent is rapidly growing its global economic impact and becoming a more attractive sourcing context. However, very little is known about current purchasing practices, successes and challenges on this continent. We investigate the specific features that characterize supply management in Africa by conducting a systematic review of the literature on sourcing in and from Africa. Our aim is to help scholars direct their future research efforts. We take a thematic approach in our analysis of 57 articles, and identify key findings, research challenges and opportunities. We focus on four areas previously identified as distinguishing the sourcing context in Africa: African culture and ethics, the role of African countries and suppliers in global value chains, an increasing emphasis on sustainability, and the gradual development of professional procurement practices. We find that research in the area of supply management in the African context is still scattered, with an evident need for more theoretically rich and methodologically rigorous inquiry. We propose a structured, theoretically grounded research agenda for each of the themes identified, and make general observations on potential future directions.

Key words: Africa, global sourcing, purchasing, global value chains, culture, sustainability

\section{Introduction}

The African continent has recently become more integrated into the global economy and is predicted to increase its future economic role: the outlook for further growth remains promising, 
and by 2040 Africa should have the world's largest working-age population (Roxburgh et al. 2010). It thus offers new and growing markets for foreign enterprises, and is a promising sourcing context for firms across industries (Gu 2009; Oke et al. 2009). In fact, some companies are leaving the previously cost-effective China and searching for suppliers in other emerging markets such as Africa (Kumar et al. 2009), which are attractive in particular because of their natural resources (Javalgi et al. 2009).

There has been a dramatic increase in the number of academic studies focusing on global sourcing and comparing purchasing across continents (Quintens et al. 2005; Manuj and Mentzer 2008; Kaufmann et al. 2012; Karjalainen and Salmi 2013), although research tends to report on sourcing from Europe, North America, and some Asian countries. Only recently have emerging markets started to attract interest (Lintukangas et al. 2010; Pazirandeh and Norrman 2014), and the African continent in particular is still in the nascent stage in terms of supply research. We identified important gaps in knowledge building in this area (Nnamdi and Owusu 2014): studies investigate agricultural products, for instance (Ouma 2012; Otchere et al. 2013), tending to ignore other sectors, and (African) scholars focus on public procurement and pay less attention to the private sector (Akenroye et al. 2012). There is an urgent need for a better understanding of supply management in Africa in the interest of both scholars and managers. In responding to this, we contrast the African context with those in other developing economies to shed light on its current and potential peculiarities. We concluded from our preliminary reading of the literature on supply management in Africa that the research was fragmentary, and that a systematic analysis was needed to provide researchers with feasible foci (Wilding and Wagner 2014). 
Given our aim to identify the specific features of current purchasing and supply-management practices in Africa, we conducted a systematic review of the relevant literature on sourcing in and from the African continent. The main contributions include our identification of the research gaps in this context and our suggested directions for research. Our approach is multidisciplinary and we aim to make a theoretical contribution to the fields of purchasing, supply chain management and international business. Our research approach includes a systematic literature review (studies up to the end of 2015), followed by a thematic analysis, and identifying potential areas for further research.

First we discuss the African context and how it compares with other countries, thus providing the rationale for our focused research effort. We introduce the contextual lenses through which we analyze the literature in the systematic review. Specifically, we identify four themes that are highlighted in the African context and make it different from the contexts in other developing areas such as Asia. We structure our analysis according to these: 1) African culture and ethics, 2) the role of African countries and suppliers in global value chains, 3) sustainability, and 4) the developing procurement profession and its purchasing practices. Second, we explain in detail the process of our systematic literature review and our analytical approach. Third, we give a brief descriptive summary of the selected studies (57 articles in total), followed by a critical review and analysis of the state of research in the field. We then formulate a research agenda for each theme, and offer suggestions on how to incorporate a more theoretically grounded approach into future studies. In conclusion, we discuss future research and summarize our main contributions. 


\section{The African continent as a sourcing context - different from other developing economies}

Various scholars have called for more studies on the African context (Acquaah 2012; Gruber and Schlegelmilch 2015). As a continent Africa is an under-researched area, specifically in the fields of international business (Lopez-Duarte et al. 2016) and CSR (corporate social responsibility): it is "much less well researched than other regions" (Kolk and Lenfant 2010, p. 241) and “a broadening of the empirical base, particularly to Africa, seems necessary” (Kolk et al. 2014, p. 360). Studies on supply in Africa are warranted not only to enhance understanding of contextspecific phenomena (such as the provision of fresh fruit), but also to strengthen (supply-chain) capabilities in the region (Narayana et al. 2014). To give a solid grounding for our analysis, we discuss the specific key features of business and society that emerged from our initial reading of the literature on sourcing from and doing business in the continent. Each of the themes resurfaced in several articles and books discussing the African context. These aspects distinguished it from other emerging contexts as portrayed in the literature on international business and purchasing, and consequently informed our subsequent literature review.

First, the African continent is unique in terms of culture and ethics. The well-known GLOBE project used data collected on cultural values and beliefs from 61 nations, and identified SubSaharan Africa as a separate cultural cluster (Gupta et al. 2002). A key feature of the sub-Saharan cultures is their non-individualistic character (Lutz 2009). A related aspect is the concept of ubuntu. This is an indigenous management concept in sub-Saharan Africa, which is similar to but not the same as that of guanxi in Asia and blat in Russia, but has attracted much less attention in management literature (Holtbrügge 2013; West 2014). Ubuntu emphasizes community and emotions in decision-making: firms must be recognized as communities (Lutz 2009; Holtbrügge 
2013). In such a culture, the individual "pursues his or her own good through pursuing the common good” (Lutz 2009, p. 314). It is claimed that in favoring solutions that satisfy all stakeholders and with its long-term perspective, ubuntu may be a source of competitive advantage (Holtbrügge 2013). Given that guanxi has been extensively studied in buyer-supplier relationships with Asian suppliers and blat in the context of emerging markets in Russia (Worm and Michailova 2003; Mattsson and Salmi 2013), ubuntu should be an equally interesting concept in African buyersupplier relationships. Naturally, cultural differences between the various countries (Woldu 2001) characterize and complicate supply chains within the African continent, and constitute an interesting research subject.

An additional but controversial ethical issue that potentially impacts sourcing in Africa is corruption. Given that, according to Transparency International indexes (Gichure 2006; https://www.transparency.org), African countries are among the most corrupt in the world, Western companies need to decide how to tackle this issue. Specific problems in supply chains include corruption by procurement officers (Adu-Poku et al. 2011) and in the signing of government contracts (Williams and Quinot 2007).

Second, Africa is becoming more integrated into the global economy and its value chains. In the light of Global Value Chain (GVC) analysis (Gereffi and Lee 2012), African firms are still among those that provide little added value. For instance, the region tends to be competitive in primary sectors, such as agriculture and food production, and in less advanced manufacturing, but there is little sign of a "factory Africa" emerging along the lines of "factory Asia", where trade in intermediates is a dominant feature (Kowalski et al. 2015). Gibbon and Ponte (2005) suggest that 
Sub-Saharan countries have generally failed to move up the value-added ladder away from the exportation of primary commodities, but there have been no studies on how global value chains and their lead buying firms could facilitate such upgrading (Gereffi and Lee 2012). Africa's position in such chains is different from other emerging economies, and the challenges related to dealing with local suppliers may be different from those faced in Asia, for example.

Third, one of the current concerns in global supply chains is sustainability (Seuring and Müller 2008; Carter and Easton 2011), which is bound to affect African sourcing. Drivers of responsible behavior clearly vary across emerging markets and countries (Baskin 2006; Phillips 2006). Two factors seem to influence sustainability in Africa. On the one hand, historical and cultural societal features (such as a collective approach to problem solving, extended families and village communities, see Phillips 2006) point to socially responsible behavior. On the other hand, globally operating companies faced with the risk of exposure in their supply chains are increasingly calling for sustainability in Africa: Schrage and Ewing (2005), for example, point to child-labor problems in the cocoa industry. Given increasing pressure from non-governmental organizations, the media and consumers, issues such as fair trade and codes of conduct are becoming prevalent in buyersupplier relationships in the developing South (Karjalainen and Moxham 2013). Sustainable business practices are expected to disseminate throughout supply chains, from (Western) end customers to the local (African) producers of raw materials. If Africa is to meet these (foreign) demands, such actions should enhance the capabilities of local suppliers (Adebanjo et al. 2013). There is a clear need for more knowledge of social and environmental sustainability in this context from a supply chain management perspective. 
Finally, greater exposure to foreign partners (Fold 2008; Ras and Vermeulen 2009; Muller et al. 2012) will influence the position of African firms as suppliers as well as their purchasing activities. Domestic purchasing practices will inevitably develop alongside emerging international interaction and international dyads with foreign buyers. The purchasing profession has gained less recognition in developing countries than in developed countries (Msimangira 2003). Moreover, research conducted in Africa seems to focus more strongly on the public sector than in e.g. other developing countries (e.g., Ntayi et al. 2011; Tukamuhabwa 2012), which raises the question of how professional purchasing is developing in private firms. All in all, the dearth of studies on the nature of companies in Africa, as well as on how indigenous knowledge is integrated into managerial decision-making (Jackson 2013) points to the need to enhance understanding of purchasing practices within the continent.

In sum, we conclude that the following contextual features influence supply in Africa: (i) the distinctive socio-cultural and ethical environments of the continent and individual countries; (ii) the current limited integration of African suppliers into global value chains; (iii) the (increasing) attention paid to social and environmental sustainability in the region's supply chains; and (iv) changes in the purchasing profession and its practices that will also influence buyer-seller relationships. Africa seems to have a unique position in all these respects, making the need for further research evident. The above-mentioned themes constitute the structure of our analysis of purchasing in and from Africa: Figure 1 illustrates our analytical framework. It highlights that although the focus of our study is a "function", i.e. purchasing and supply chain management, we take into account different levels and units of analysis, both at company and contextual level. In other words, the issues investigated relate to company practices, the buyer-seller relationships, the 
overall context, and the pressures arising from stakeholders overall.

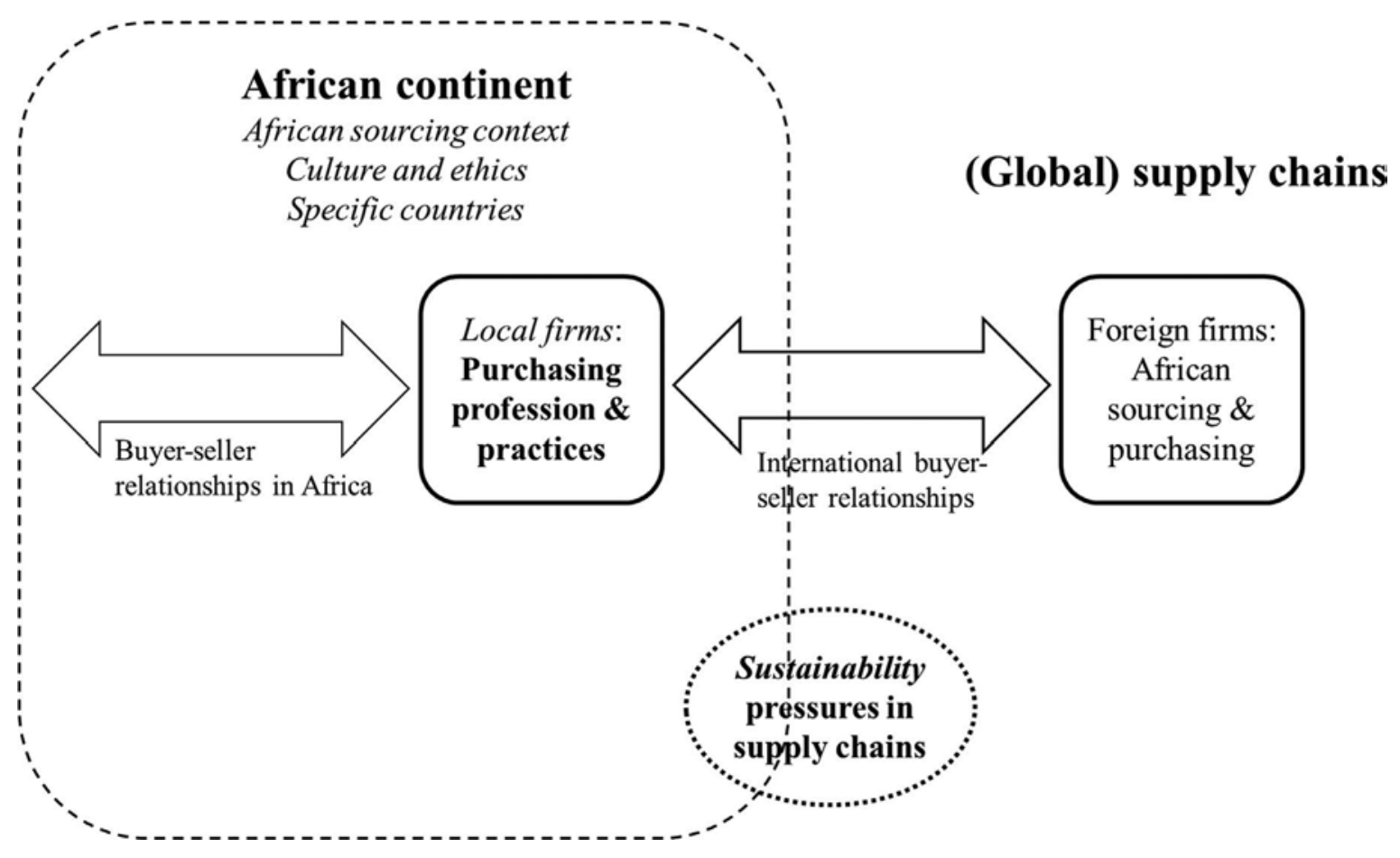

Figure 1. The framework: key analytical themes

The four general themes reflect the need for a broad perspective: it is necessary to consider supply, sourcing, and purchasing at both the strategic and the tactical level to enhance understanding of Africa as a sourcing context. We thus adopt an inclusive approach in our literature review. We also question the suitability of existing theories and concepts. Indeed, concerns about the validity of theoretical approaches developed from a different (mainly Western) perspective go hand in hand with calls for more research in new contexts such as Africa (Karjalainen and Salmi 2013; LopezDuarte et al. 2016). 


\section{Methodology}

We aimed in our literature search at a comprehensive coverage of scientific articles focusing on sourcing and/or supply management in the African continent. We included articles in which sourcing in and/or from Africa is discussed from various perspectives, incorporating the features of supply chains and corporate purchasing strategies as well as the practices of buying in and from Africa adopted by local and foreign companies. We adopt Monczka and Trent's (1991) definition of "global sourcing": the integration and coordination of procurement requirements across worldwide business units, looking at common items, processes, technologies, and suppliers.

Meredith (1993) refers to literature reviews as valid tools for synthesizing and refining scattered knowledge regarding different stages of research. Such reviews also make a scientific contribution in themselves, in terms of mapping, consolidating and developing theory in certain research areas, and creating a basis on which to build future research (Seuring and Gold 2011). There is a particular need in emergent research fields, such as global sourcing in general and in emerging markets in particular, to devise a research agenda grounded in the literature. This grounded approach will facilitate the synthesis and refinement of the narrow, separate studies published thus far into a framework within which to identify unexplored topics and suggest suitable directions for research, theory testing and development (Angell and Klassen 1999; Youngdahl et al. 2010). Given that context is at the core of all international business and global sourcing studies, we emphasize the African supply context in our review, which is in line with evidence-based and multidisciplinary management studies (Jones and Gatrell 2014). We therefore started our analysis by identifying the four above-mentioned themes. 
We wish to emphasize that our aim is not to 'lump together' the African continent in terms of culture, purchasing and supply practices, and emerging challenges. We recognize that countries within the continent vary in their institutional elements, infrastructure, languages and cultural background, all of which affect business practices. However, given that research on the continent as a whole, and in each country within it, is at a formative stage, we feel that we should first take an overarching perspective on the work done within the African context and thereby identify overall themes and key findings of past research, note the countries that have been the focus of study, and find out the extent of context-specific understanding. We therefore highlight the specific context of each study, and emphasize the need for emic, locally and culturally specific theory testing in our suggestions for a future research agenda.

Cooper (1988) presents a taxonomy that categorizes literature reviews in terms of focus, goal, perspective, coverage, organization, and audience, on which we rely as we describe our review. Table I summarizes this taxonomy and our perspective. Our approach is interpretive (DixonWoods et al. 2006) and qualitative (Jones and Gatrell 2014) in nature. We present descriptive data on all the articles we identified (see Appendix 1), but focus on issues that appear to warrant the most attention on the basis of our initial structuring of the topic i.e. we promote or espouse these key areas (Cooper 1998). Furthermore, although we base our conclusions on the entire set of selected literature, we describe only a sample of the works in detail. Our approach is focused but multidisciplinary, which we believe will enhance future research. 
Table 1. Current study related to Cooper's taxonomy

\begin{tabular}{|c|c|c|c|}
\hline Characteristics & Categories & This study & Additional notes \\
\hline \multirow{4}{*}{ Focus } & Research Methods & $\mathrm{X}$ & \\
\hline & Research Outcomes & $\mathrm{X}$ & \\
\hline & Theories & $\mathrm{X}$ & \\
\hline & Practices and Applications & $\mathrm{X}$ & \\
\hline \multirow[t]{3}{*}{ Goal } & $\begin{array}{l}\text { Integration } \\
\text { (a) Generalization } \\
\text { (b) Conflict Resolution } \\
\text { (c) Linguistic bridge- building }\end{array}$ & & \\
\hline & Criticism & $\mathrm{X}$ & $\begin{array}{l}\text { Critically analyzes the existing literature on supply } \\
\text { (chain) issues in Africa }\end{array}$ \\
\hline & Identification of Central Issues & $\mathrm{X}$ & $\begin{array}{l}\text { Identifies questions that should dominate future } \\
\text { endeavors }\end{array}$ \\
\hline \multirow[t]{2}{*}{ Perspective } & Neutral Representation & & \\
\hline & Espousal of Position & $\mathrm{X}$ & $\begin{array}{l}\text { Picks the issues that seem to need most attention on } \\
\text { the basis of our initial structuring of the topic }\end{array}$ \\
\hline \multirow[t]{4}{*}{ Coverage } & Exhaustive & & \\
\hline & Exhaustive with Selective Citation & $\mathrm{X}$ & $\begin{array}{l}\text { Bases the conclusions on an entire set of selected } \\
\text { literature, but describes only a sample of works in } \\
\text { detail in the paper }\end{array}$ \\
\hline & Representative & & \\
\hline & Central or Pivotal & & \\
\hline \multirow[t]{3}{*}{ Organization } & Historical & & \\
\hline & Conceptual & $\mathrm{X}$ & $\begin{array}{l}\text { Organized conceptually so that the works that relate } \\
\text { to the same abstract ideas appear together. }\end{array}$ \\
\hline & Methodological & & \\
\hline \multirow[t]{4}{*}{ Audience } & Specialized Scholars & $\mathrm{X}$ & $\begin{array}{l}\text { Scholars in the fields of Supply (Chain) } \\
\text { Management, Operations Management, and } \\
\text { International Business }\end{array}$ \\
\hline & General Scholars & & \\
\hline & Practitioners or Policymakers & & \\
\hline & General Public & & \\
\hline
\end{tabular}

\section{Search protocol}

A systematic literature review based on a detailed search strategy is more likely to produce replicable results (Tranfield et al. 2003). Inclusion and exclusion criteria are specified beforehand. Potentially relevant sources identified during the first review are evaluated thoroughly before the final selection is made. We base our analysis on Pittaway et al. (2004) and Müller-Seitz (2012).

The review process started in 2013 (and ended in 2016), but no back limit was set to the "age" of the papers. As a result, our analysis covers 57 articles published in peer-reviewed journals from 1986 to 2015. The first stage of our literature review consisted of a full-text search of three 
databases (ProQuest, ScienceDirect and Ebsco) using keyword combinations related to Africa and sourcing. Each sourcing-related keyword was combined with the word Africa*, which generated a total of nine search strings (see Table 2). In line with Müller-Seitz (2012), we generated a list of keywords with a broad coverage even though they also generate a high number of irrelevant hits. We limited our search to scientific/peer-reviewed articles in the English language. Although this may have prevented us from discovering all the relevant research (some may have been conducted in French, for example, or restricted to university publications), we feel it was justified to focus on the common scientific knowledge base thus far, which English-language scientific journals represent (e.g., Deng 2012).

Table 2. Keywords used in the systematic literature review

\begin{tabular}{ll}
\hline Africa - keyword & Sourcing-related keywords \\
\hline Africa* $^{*}$ & Buy*; ; Procur*; Sourcing; Purchas*; 'Supply chain'; SCM; Outsourc*; Offshor*; Supplier \\
\hline
\end{tabular}

It is typical in many disciplinary fields and publications to focus on certain subsets of research. To ensure a wider coverage we decided to search in several reliable databases rather than to focus on individual journals, which is in line with our multidisciplinary approach. A recent review was published in the field of international business, covering sourcing and logistics in Africa (Nnamdi and Owusu 2014). However, as it included only a selection of journals and focused on sub-Saharan countries it yielded a much more limited sample of articles and discussion than in this study.

The article search yielded 5,029 hits in total and identified 4,117 unique articles, of which 203 made it to the second round for a more detailed review. 
Figure 2 comprises a flow chart of the review process. In line with Müller-Seitz (2012), we used pre-defined inclusion and exclusion criteria, and the depth and level at which the papers were reviewed increased throughout the process. The first review round consisted mainly of evaluating the titles of the articles, examining the abstracts if necessary, and briefly reviewing the full text in some cases. At this stage we were highly inclusive: we paid no attention to whether the article focused completely or in part on the topic, the point being to identify all articles that could shed light on the topic. For instance, we included an article in which a location in Africa was among the several cases discussed. We excluded studies discussing trade issues and policies at a general or country-to-country level, but included public procurement because it deals with public administration as an organization buying goods or services for its own use. We also excluded articles on consumer purchasing behavior and book reviews.

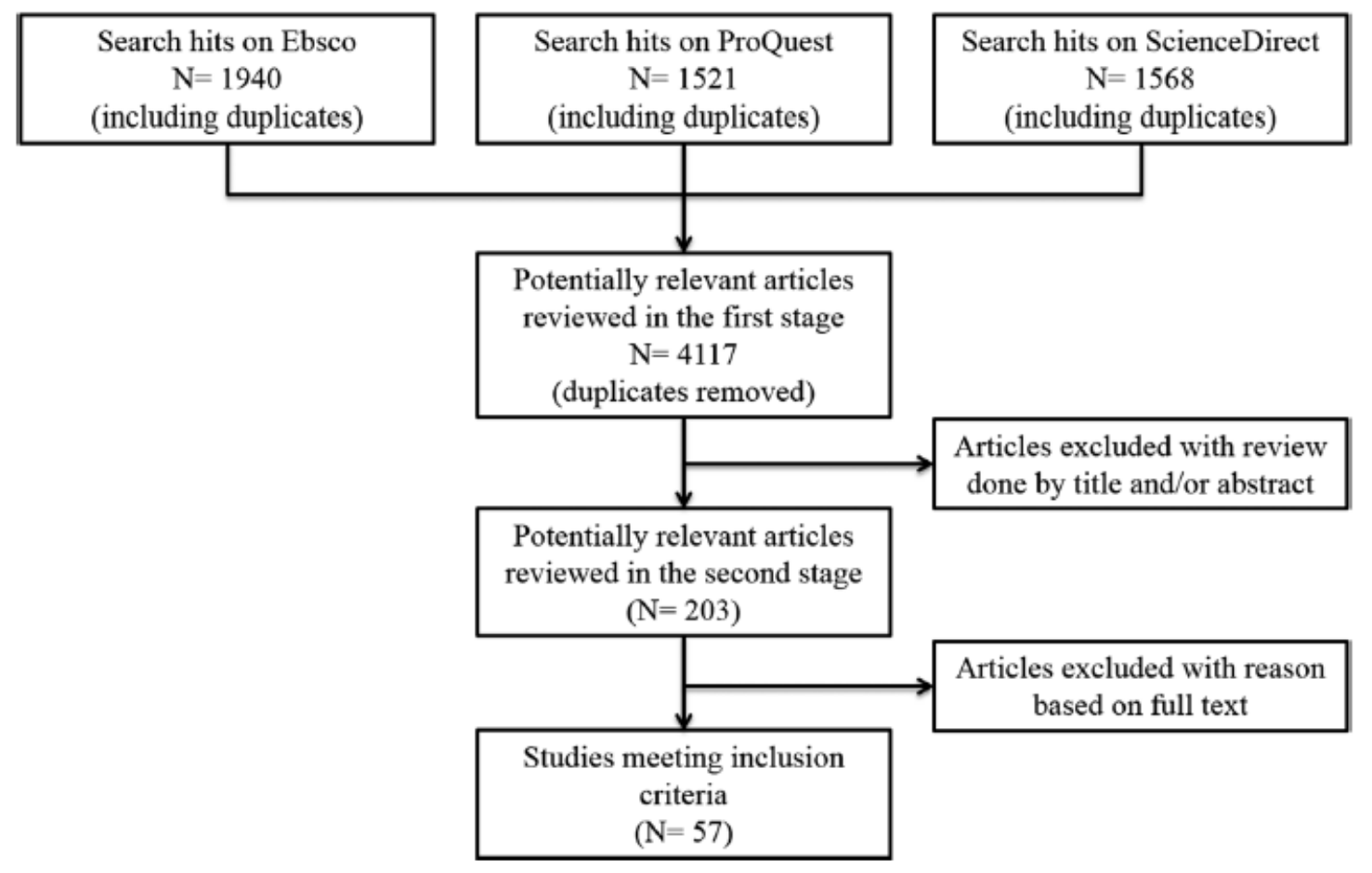

Figure 2. The process of the systematic literature review 
We tightened the inclusion criteria in the second-round review of the remaining 203 articles and only accepted those making a significant contribution to existing knowledge of purchasing and supply in Africa. Thus, we only accepted those that focused totally on or provided major insights into the issue, in other words in which the African context and its impact clearly related to purchasing and/or supply chains and the findings were derived from this relationship. We excluded articles in which African countries or an African firm or supply chain were only used to contextualize a purchasing-focused research question, and the context was not discussed in relation to the findings (e.g., managers of African and other nationalities may have been among the respondents to a supply-chain-related survey, but the subsequent analyses did not consider the effect of the African origin on the issue under investigation). Thus we only considered articles that enhanced understanding of purchasing or supply-chain management in this particular context, yet included those in which the main focus was on another topic but that still shed light on the phenomenon in question.

During this second stage of the process the three authors reviewed all the articles based on a reading of the full text. First, all three coded 10 percent (20) of the 203 articles independently as either green (definitely accepted), yellow (possibly accepted), or red (rejected) - a method adopted from Kauppi et al. (2013). These codes were then compared to check for inconsistencies. We discussed the inconsistencies until we reached an agreement, and refined the inclusion criteria. We then divided the remaining articles to be reviewed equally among us. Finally, after the second round of reviews we had 57 articles for the thematic literature analysis, which all three authors reread for content analysis. The researchers thus read, analyzed, coded and classified all the articles and were able to benefit fully from working in a team (Jones and Gatrell 2014). Without doubt, 
this team work, i.e. analyst triangulation (Patton 1990, p. 468), enhanced the reliability and validity of the analysis.

\section{A descriptive review of the literature}

Before moving on to thematic analysis, we briefly review the selected articles to provide information about the sample (Seuring and Gold 2011). The 57 reviewed articles were published in 41 different journals. Of these, the International Journal of Business and Social Science and the Journal of Business Ethics featured the most (five and four articles, respectively). Supply Chain Management: An International Journal had published three articles, whereas certain other journals, namely Development Southern Africa, the European Journal of Development Research, the Journal of Global Business Issues, the Journal of Public Procurement, Regional Studies, the South African Journal of Business Management, and Sustainable Development had published two. The rest of the journals (31) had published just one relevant article. Figure 3 gives the publication years: most of the articles were published during the past ten years, and there is a moderately increasing research trend in this area.

Figure 4 presents information on the authors' research affiliations. The dominance of South Africa is predictable given that it is more highly developed compared with other countries on the continent. Several countries are former colonies of the UK, with which they have maintained close connections since independence, thus it was not surprising to find research on Africa conducted by British scholars. 


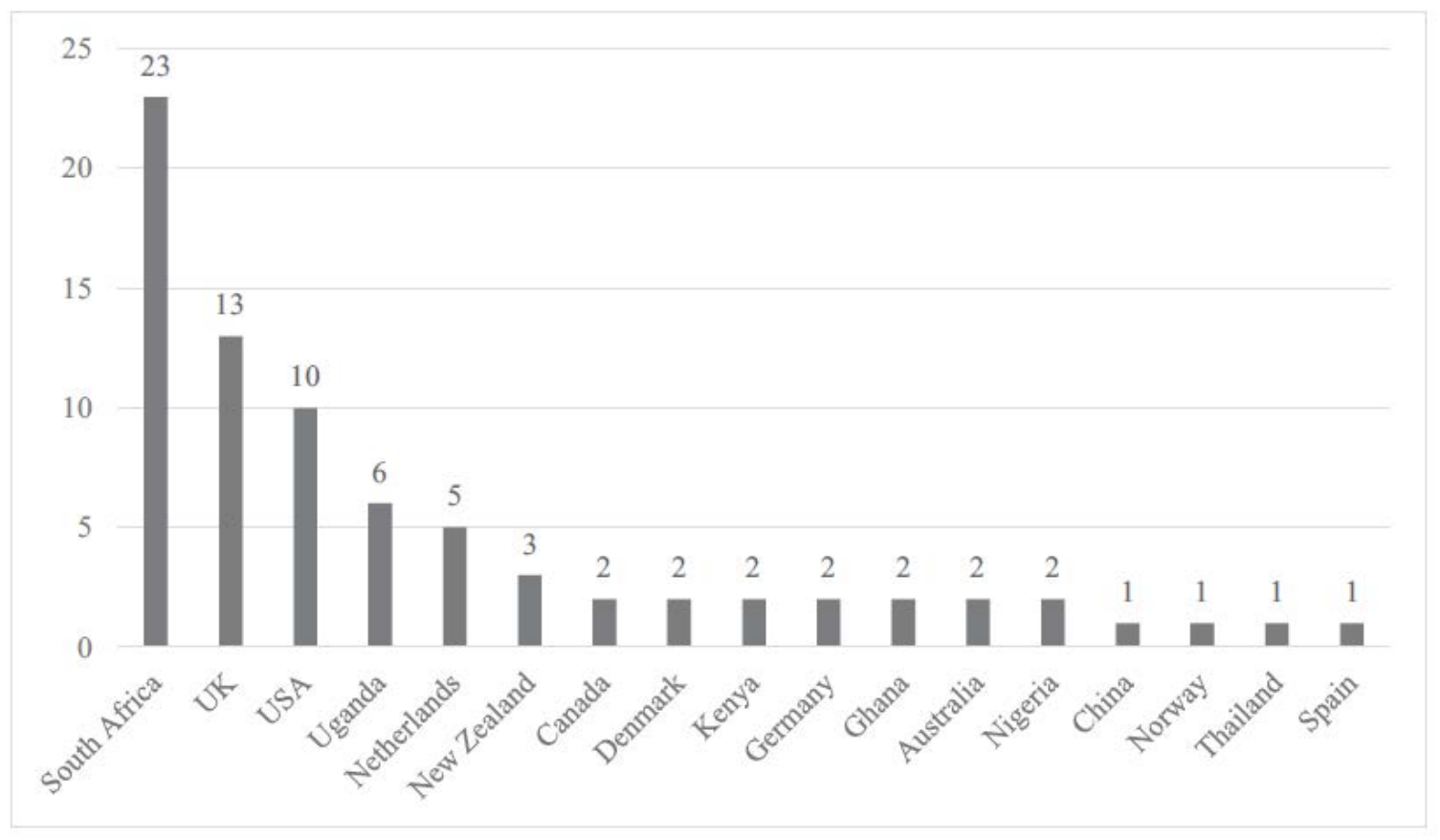

Figure 3. Numbers of articles published per year

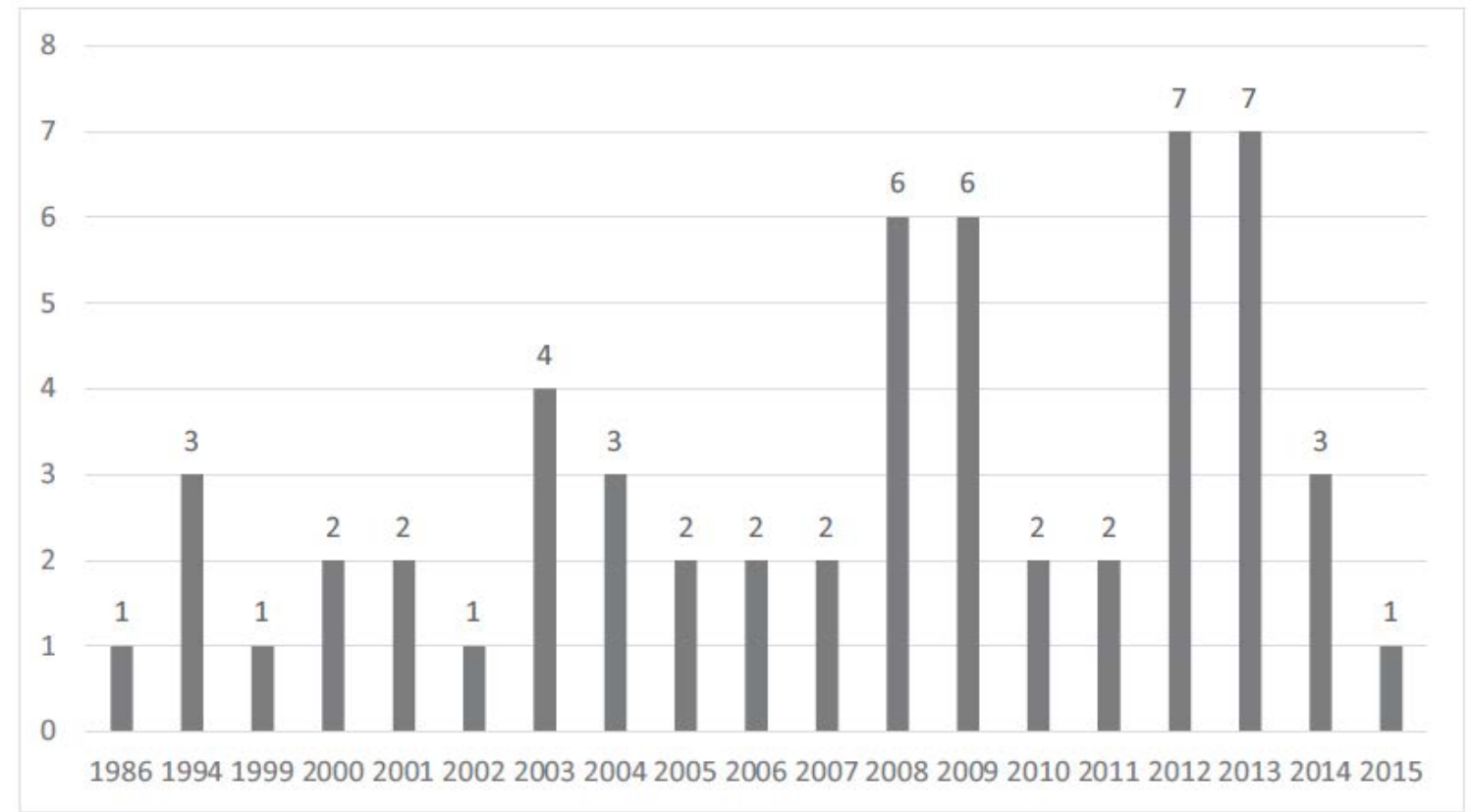

Figure 4. Research affiliations

Of the 57 articles, 22 were (co-)authored by scholars with an African affiliation, 22 by scholars 
with a non-African affiliation, and 13 by representatives of both African and foreign research institutions. South Africa was the most strongly represented in terms of research affiliation (25/57, that is, almost $30 \%$ ), and as Figure 5 shows, this context also yielded the most articles (27).

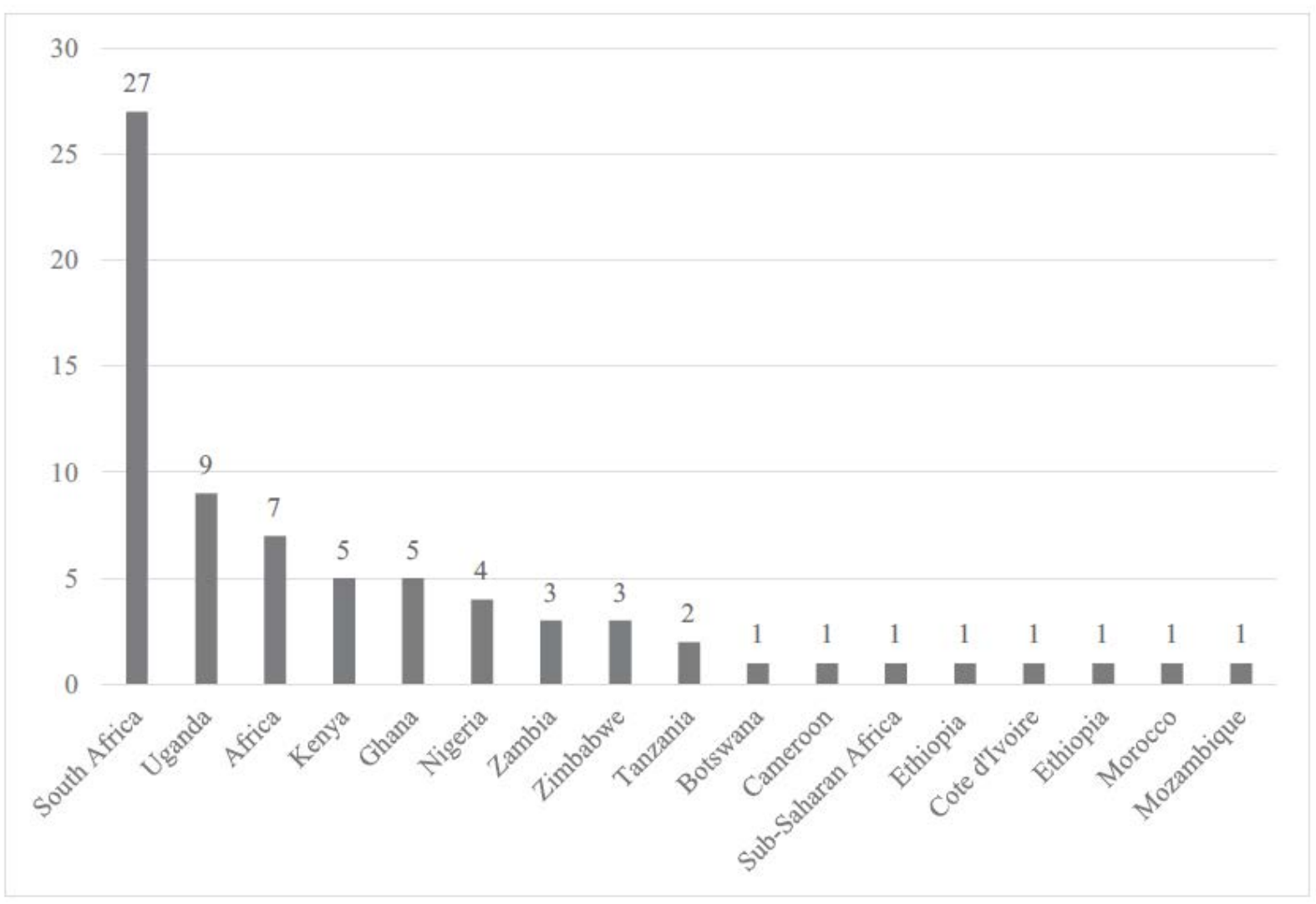

Figure 5. The countries under study in the selected articles

Figure 6 shows the distribution of the research methodologies in the articles: survey was the most commonly used method (21 articles), other popular methods included case studies and interviews (17 and 16 articles, respectively). 


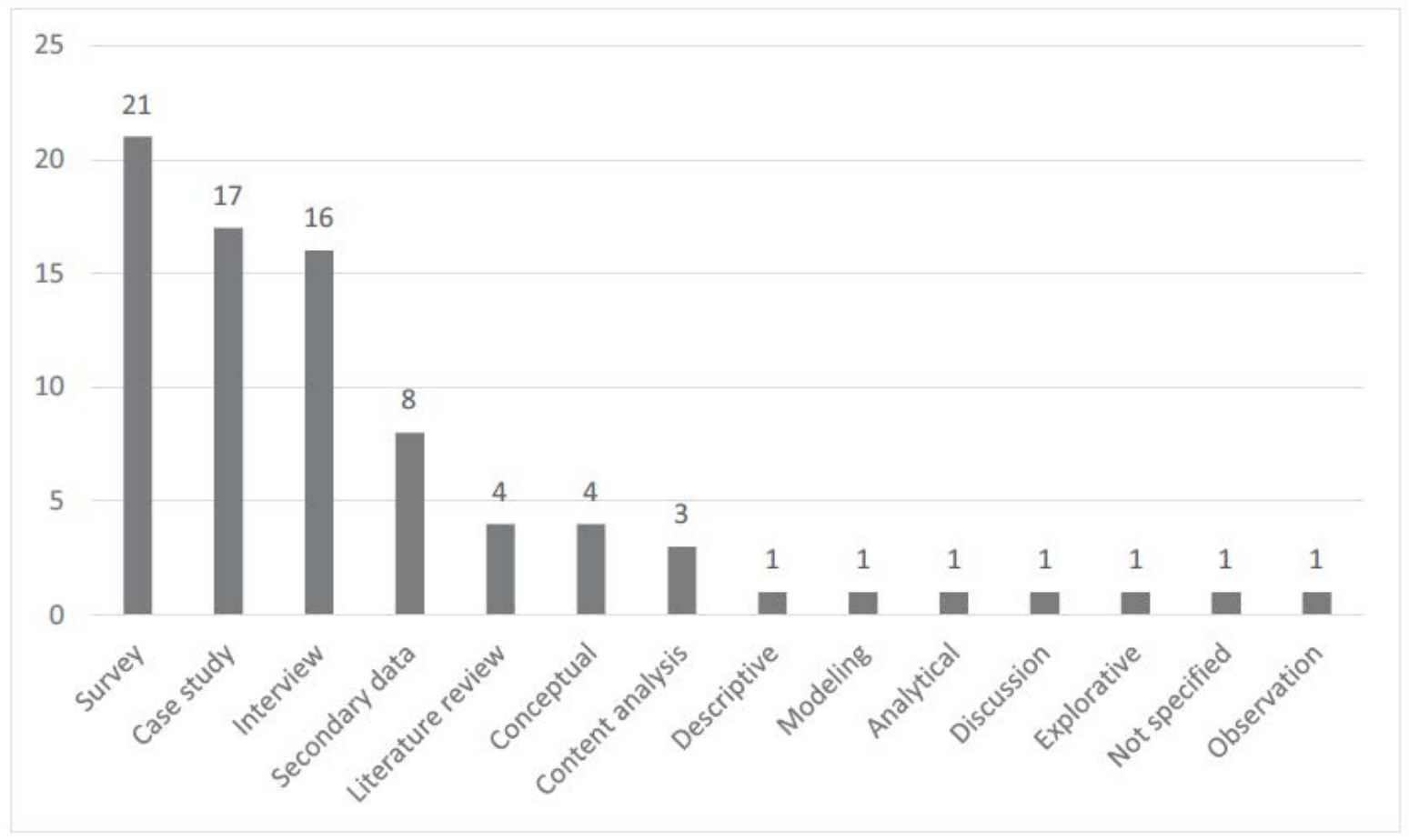

Figure 6. The research methodology used in the selected articles

With regard to methods, however, we found frequent omissions in terms of data-collection details (e.g., Muhwezi 2007) and sampling (e.g., Adeley et al. 2004), although many used opportunity/convenience sampling (e.g., Cilliers and Nagel 1994; Oke et al. 2009; Ras and Vermeulen 2009). Ways of reducing bias were not commonly discussed, which is a shortcoming in itself but also makes it difficult for future researchers to estimate typical response and other biases among African respondents. Moreover, some of the survey and interview studies failed to disclose or clarify the detailed data-collection methods and/or respondent numbers (e.g., Moodley 2002; Msimangira 2003; Adeley et al. 2004; Asamoah et al. 2013). Golooba-Mutebi (2003), for example, only states of methods: "The study was conducted through in-depth one-to-one semistructured interviews with local politicians; civil servants; members of non-governmental organisations; members of the public; and representatives of private contractors. Official and 
unofficial documents, newspapers articles and reports by contractors were reviewed. In addition, various garbage-dumping sites in the city were visited." The reader thus remains ignorant of respondent numbers, the length of the interviews, and the questions, as well as of how conclusions were reached based on the data. Coding frameworks were rarely used in the qualitative studies, and few respondent quotations were presented (e.g., Nollet et al. 1994). All in all, future studies should be more transparent in their reporting, and more rigorous in terms of reliability and validity.

Appendix 1 also notes the theories used in each paper, or if a theory appears not to have been used at all, based on the descriptions in the papers. We have used both our own assessment as well as the authors' statements in deciding what (not) to include in the column indicating the used theory. In some cases the author does not explicate the theory, but its use appears evident from the discussion (e.g. use of Transaction cost theory by Fisman and Ghosh 2005). In other cases (e.g. Lacity et al. 2014), the authors go through a large number of theories, but actual application of them is, however, very superficial or non-existent in the analysis itself. Institutional theory and transaction cost theory (applied four times each) are the most used in our sample, along with the global value chain approach (used twice). Overall, only 15 of the 57 papers use a theory/ies to ground the analysis.

\section{Analysis of the literature}

The main goal in reviewing the literature was to highlight the features of sourcing in and from African countries, and to identify key areas for future research. We structure our analysis in line with the four distinctive features of the African context, as mentioned earlier. 


\section{Cultural and ethical issues}

Awareness of the institutional and cultural context and its influence on business relationships is critical in terms of understanding purchasing in Africa. Some of the studies shed light on the institutionally changing African context, but relatively few describe the communal features of the business culture. There are also some references to ubuntu, as well as to corruption and ethical issues in African supply.

The influence of the institutional setting is evident in Sartorius and Kirsten's (2005) study, for example. According to the authors, a major reason to why sugar producers in Southern Africa outsource sugarcane production is the social pressure to contribute to the transformation of the agricultural sector. These producers thus expanded small-farm supply although this was clearly in conflict with profit maximization.

Some of the studies focus on interpersonal networks, thereby reflecting the importance of the community and ubuntu. Fold's (2008) analysis of transnational sourcing practices in perennial crop sectors in Ghana refers to the widespread ethnic-based business networks that include traditional leaders of rural communities. Contacting the leaders may help transnational sourcing, which is influenced by the need for immediate processing. Miller (2008), too, refers to the local community in the context of Zambian suppliers and a South African retailer. His study reveals how a community of farmers first resisted the expansion of the retail company, but eventually a participatory arrangement was made for the villagers to supply it. All in all, we found surprisingly little research on the role of local indigenous community networks in purchasing and supply, and the non-individualistic and communal nature of African cultures is rarely mentioned. 
In fact, we expected a heavier presence of the ubuntu phenomenon, but it is only discussed in two studies. Miller (2008, p. 40) refers to it as a "shared, non-racial, democratic value system" that is reflected in the organizational cultures of African firms. Muller et al. (2012, p. 129-130) define ubuntu as "an African cultural system focused on collectivism rather than individualism”, which "represents the core values of African life". They suggest that business considerations from the African perspective relate not only to price and economic principles, but also to trust and loyalty in the value chain, as ubuntu values imply. Cultural values are a determinant of the embedded social responsibility within a supply chain, and therefore affect the management strategies of the chain and the individual businesses. The articles discussing ethics in the supply context ignore the positive community focus of ubuntu, stressing negative ethical behaviors and corruption. Badenhorst (1994) studied procurement ethics in South Africa, noting that the purchasing environment was conducive to unethical behavior: this was not necessarily attributable to individual moral standards, but rather reflected management behavior, the ethical climate of the enterprise, and the absence of a company policy. Two studies (Ntayi et al. 2011; Tukamuhabwa 2012), which focus on unethical and noncompliant behavior in Ugandan public procurement, also mention the organizational climate and environment as contributing factors to such behaviors. Tukhamuhabwa (2012) describes non-compliant behavior as rampant in Uganda. Ntayi et al.'s (2011) study identifies anomie, weak procurement planning, and the psychological climate as the key causes of unethical conduct in public procurement; they imply that procurement officers have lost their sense of stewardship. The issue of corruption in African supply in general comes through in the literature. Nollet et al. (1994) and Gu (2009), for instance, list the challenges facing companies sourcing from African countries, including issues such as a lack of hard currency, 
inflation and exchange rates, policy uncertainty, communication issues, corruption, crime, theft and disorder.

The role of African firms in global value chains

The integration of African companies into global value chains is discussed with regard to several industries. Overall, low costs and the availability of raw materials are the key factors bringing supply chains to the continent. Most studies do not specify the countries, but rather emphasize the key benefits of the continent as a whole as a source of supply. Issues of infrastructure, technology and the quality of work plague both local and foreign buyers, however, and appear to block more value-adding positions in global chains.

Barnes and Morris (2008) used the South African automotive industry as a case study to present the opportunities and challenges facing manufacturers in developing economies in the global value chain. They reveal the importance of an appropriate macro and sectorial industrial policy environment, and point to the necessity of developing world-class manufacturing capacities in developing economies competing against larger players from both developed and developing countries.

We found some analyses of networks involving various types of organization, conducted in particular by scholars investigating retailing. The African retailing sector is experiencing major transformation, as informal traditional markets are integrated into and replaced by formal structures. This calls for interaction between small local producers and large (international) retailers (Weatherspoon and Ross 2008), as well as partnerships between stakeholders in the public 
and private sectors (Boselie et al. 2003). In this context, various stakeholders such as farmers, farmer organizations, the government, and retail businesses use different mechanisms to ensure that small producers are integrated into the changing supply chains (Louw et al. 2007).

A topic that is closely related to the role of African suppliers in global value chains is the drive to source from the African continent. The studies we found do not typically differentiate between individual countries (e.g., Gu 2009; Oke et al. 2009), or focus on the supplier level, but rather include African sources of supply as overall drivers in their chains. Low costs and the availability of raw materials prevail among the reasons identified. Oke et al. (2009), for example, suggest that sourcing from African countries rests on the availability of raw materials: Africa has the best weather conditions and the natural resources for growing the necessary materials (Gu 2009). The low cost of labor is another reason why companies from elsewhere source from Africa (Oke et al. 2009). Low costs also feature strongly in the outsourcing decisions of local African organizations (Johnston et al. 2009; Sang 2010), and purchasing units are seen as cost centers (Akenroye et al. 2012). Thus the academic literature may contribute to upholding the view of African suppliers as sources of cost rather than value. However, low costs may not be the only reason why Westernbased firms are attracted to Africa. Lacity et al. (2014) point out the advantages of South Africa as an outsourcing destination, including its encompassing economic value, high-quality service and staff, strong cultural compatibility, and the favorable time zone.

Private Chinese enterprises appear to source from Africa for a wider variety of reasons, including access to local markets, intense domestic competition, the opportunity to transfer excess production capacity, diversifying risk and financial incentives from the government (Gu 2009). 
This would suggest that Chinese, as opposed to Western firms, perceive African firms as playing a more versatile role in their value chains, possibly enhancing their own roles. One driver that was not identified among Western companies but was evident among Chinese companies, for example, is the chance to take advantage of African regional and international trade agreements (Gu 2009).

Why are African firms typically viewed so narrowly in terms of their potential as a source of supply? The reviewed articles list a multitude of challenges facing both local and foreign organizations that may prevent suppliers from assuming more advanced roles and engaging in more value-added activities in global chains. Typical issues include long lead times, poor-quality products and services, and deficiencies in terms of regulations, infrastructure, technology, and skilled personnel (Lowson 2001; Cunden and Van Heck 2004; Miller 2008; Ahimbisibwe et al. 2012). The problem of long lead times is not restricted to outsourcing within Africa, and affects African sourcing in general. As Elbadawi et al. (2006) point out, African companies are located further away from wealthier or more densely populated potential export markets, and African manufacturing companies also pay higher input prices due to their long distance from cheaper foreign suppliers. Consequently, African companies are not expected to improve their position in value chains in the immediate future (Kotabe and Mudambi 2009).

Moodley and Morris's (2004) study on garment-exporting firms in South Africa illustrates the typical positioning of African firms in global value chains. Exporters are only contract manufacturers, their export market is highly intermediated, and they have little contact with end customers. Furthermore, the firms are limited in their uptake of e-commerce, which is becoming increasingly important in global trade. Infrastructure-related challenges are also frequently 
mentioned, and specifically in relation to seed supply chains in Sub-Saharan Africa (Martens et al. 2012), and outsourcing in the banking industry in Nigeria (Adeleye et al. 2004). A lack of up-todate technology, resulting in poor-quality products and the inability to meet set deadlines, is a major constraint on subcontracting among manufacturers (Okatch et al. 2011; Ambe 2014). Cilliers and Nagel (1994) reveal a lack of both holistic management and integrative systems in South African logistics practice; this is confirmed in Rodrigues and Potter's (2013) study conducted two decades later. This lack of infrastructure limits the potential involvement of African companies in global value chains. Barnes and Kaplinsky (2000a; 2000b) note a further effect of globalization: subsidiaries of South African vehicle-assembly firms are integrated into the global operations of their parent companies, which forces them to source foreign components, and as a result local automotive-component suppliers using local technology go out of business.

According to Workneh's (2014) study on the Ethiopian-Italian leather trade, however, African firms are striving to get their fair share of the added value derived from upgrading through the value chain, and traditional strategies deployed by Western-based firms no longer seem to work. Nevertheless, given the long list of challenges facing African suppliers, there are several barriers that local companies need to overcome before they can assume more high profile roles and more value-adding activities in global value chains.

\section{Sustainable business in African sourcing}

Social and environmental sustainability affects all contemporary businesses and has attracted increasing attention in sourcing from African countries. Several studies illustrate the relevance of collaboration, involving companies and NGOs, in achieving sustainability (Muller et al. 2012), 
and show how calls for sustainability travel from (Western) consumers to local African producers (Dos Santos et al. 2013). Although Western buyers are striving to improve sustainability at source, more local and context-specific solutions are required to ensure a fit with the characteristics of African communities.

Ras and Vermeulen (2009) investigated sustainable production and the environmental performance of South African producers of table grapes in a global supply chain. They found that business-tobusiness interactions positively affected the environmental performance of producers. According to a related study on global supply chains by Muller et al. (2012), a collaborative approach, with companies and NGOs working together, is more likely to result in long-term sustainability change than a prescriptive approach. Muller et al. (2009) found in an earlier study that the perceptions of European and South African stakeholders were indeed different. Thus, in terms of sustainable development it is important to acknowledge the roles of local stakeholders, NGOs, market players and national governments in global supply chains.

Huang et al. (2013) note a worrying trend regarding environmental and social sustainability in the forest industry caused by a shift in exports to China from mainly Western markets. As Chinese customers do not push African producers to obtain certifications as strongly as Western customers do, the dissemination of such standards to African forest-industry supply chains is at risk. Adebanjo et al. (2013) regard CSR issues as a weakness of Nigerian suppliers, specifically in relation to health and safety, workmanship insurance, and tax payment. 
Another sustainability issue is fair trade. Smith (2010) studied fair-trade business models in the UK supermarket sector and found differences in commitment as well as in the handling of relationships with African suppliers: such differences should perhaps be reflected in the labeling, and fair-trade organizations could reward those demonstrating greater commitment. Blowfield and Dolan (2008) investigated the ethics embedded in and promulgated through ethical trade in African agriculture. They describe ethical trade as a neo-utilitarian response to globalization, and by means of illustrative examples suggest that Western views of CSR and its implementation may not always coincide with the views of African suppliers.

\section{Developments in the purchasing profession and its practices}

The main emphasis in the studies focusing on the purchasing profession and its development in Africa is on public procurement, and on two countries: South Africa and Uganda. There is clear evidence of an underdeveloped profession. Somewhat surprisingly, there is an apparent lack of prescriptive research examining good practices, and only a few articles discuss the handling of buyer-seller relationships.

The studies on public procurement in Africa give a regrettably negative image of the state of the profession. According to Pooe et al. (2015), aspects such as a lack of training, capacity and transparency, and the failure to comply with existing public-procurement policies, make it difficult for municipalities in South Africa to achieve their procurement objectives. Ntayi et al. (2011) describe how the public procurement environment in Uganda suffers from interference by political parties, a poor professional image, and the absence of qualified personnel and supporting IT. Moreover, despite typical benefits such as lower costs, efficiency improvements and better service 
quality, public-sector outsourcing also faces challenges such as negative attitudes among staff, poor monitoring, and interference from the community (Sang 2010), as well as a shortage of resources such as equipment, and power struggles between associated parties (Golooba-Mutebi 2003).

It is suggested that the private sector faces similar challenges (Benner 2006; Okatch et al. 2011; Otchere et al. 2013). There is evidently a strong need to educate local staff to meet the requirements of global business. Various authors refer to the lack of skills and of suitably educated workers: Muller et al. (2012) in their study of the British-South African fresh-fruit supply chain; Benner (2006) in his study of South African call centers; Ambe (2014) in a study of light-vehicle manufacturing in South Africa; and Akenroye et al. (2012) on the subject of Nigerian financial services.

Only a few studies in our sample give advice on supply-chain management in the African context, mostly with regard to foodstuff chains. Boselie et al. (2003) report that some African supermarkets use their staff to supervise and inspect crops, and cultivate exclusive supplier-buyer relationships in procuring from local suppliers. Fold (2008), in turn, suggests that transnational buyers should ensure the immediate processing of the crop after harvesting in Ghana to achieve product differentiation.

Some of the reviewed studies focus on interaction and purchasing practices in buyer-seller relationships. They acknowledge the role of trust building in developing supplier relationships. Ouma (2012), for instance, discusses the practicalities and relational investments required to 
ensure that farmers become aligned to a multinational fruit-processing company in Ghana: it was critical for the cooperation to foster a culture of mutual respect and to build trust. Similarly, as Moodley and Morris (2004) note in their analysis of the use of e-commerce technologies among garment-exporting firms in South Africa, the aim is to cultivate long-term relationships built on trust. Relationships between sellers and buyers in this sector tend to be highly personalized, and depend on non-contractual activities and complex information requirements.

\section{Discussion}

Before discussing the themes and related potential avenues for further study, we will comment briefly on the overall quality of the research. Although there are notable exceptions, much of it is reported in journals that do not feature (or rate very low) in the ranking of international journals such as in the Academic Journal Guide 2015 or the Journal impact factor database. Of the 57 articles, 15 were published in journals with an AJG rating of three, 12 with a rating of two, and five with a rating of one: the remaining 25 were published in journals that are not listed in the AJG. Furthermore, 24 articles (42\%) were published in journals without a journal-impact factor. The 23 articles that appeared in journals with an impact factor of over 2.0 were published in 2000 or later. It is somewhat surprising that research on this context has not yet penetrated the top outlets. Research must start somewhere, however, and we hope this review will encourage more scholars to target the African context. Much of the evidence so far could only be considered anecdotal, and hence there is an evident need for more stringent, methodologically transparent, large-scale replication, as well as carefully designed case-studies. Indeed, scholars need to pay careful attention to the quality of their research methods in purchasing and supply (Knight et al. 2016), 
when addressing the increasingly interesting African context. We also stress the competitive edge of African scholars in conducting and valuing indigenous research, which we believe sends an encouraging message to the research community.

\section{Theme-specific research avenues}

We structured our review around four previously identified themes emphasizing the specificity of Africa as a supply source compared to other (developing) country contexts. Figure 7 is a revised version of Figure 1, to which we have added information on how the reviewed papers cover the different topics (see the numbers shown in circles). Figure 7 also highlights the main research gaps noted during our analysis in the form of key suggestions for future research areas related to each theme. These research suggestions are presented in Table III and discussed in more detail later on. As our analysis showed that most of the studies (almost 75\%) have not grounded their analysis on strong, established theoretical bases, we suggest some theoretical lenses for each theme, along with compatible research questions. 


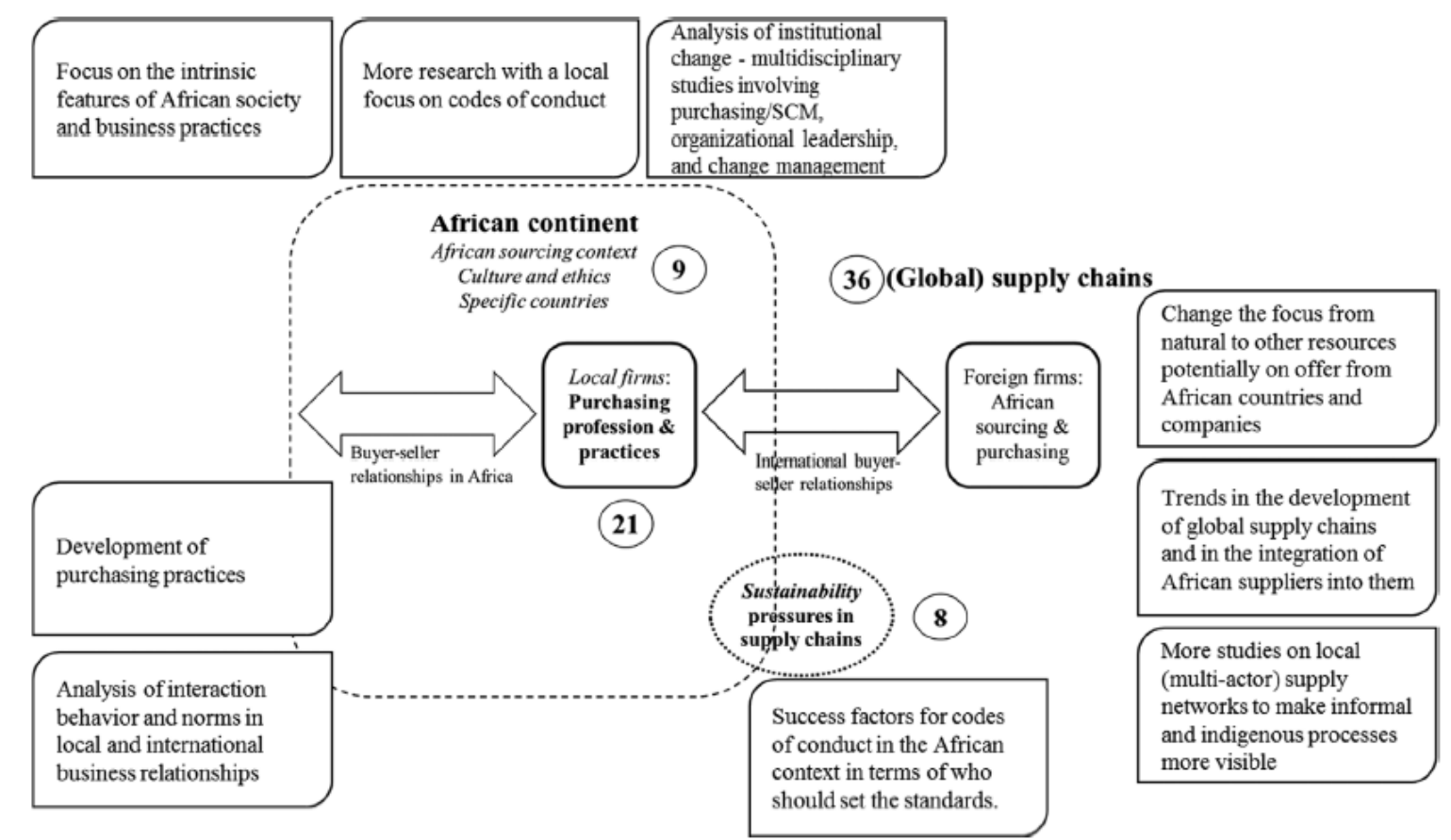

Figure 7. Findings from the theme-based review and future research directions

We derived the four themes from our initial reading of the existing literature, and conclude that they aptly illustrate the current focus areas of research on sourcing in and from Africa. The results show the relative proportions of topic coverage, as well as the relative coverage of the individual African countries (see Appendix 1). Our premise with the four themes was that several units and levels of analysis should be present given the particular characteristics of African continent. However, Figure 7 shows that the research area that is potentially most "fruitful" in terms of differentiating findings from the Western and Asian contexts, i.e. Africa as a sourcing context has received very limited attention. We thus suggest more research with a focus on the intrinsic features of the continent in a business setting, as well as in defining sustainable sourcing for example.

On the basis of our analysis, we are able to add some nuances to the big picture: there are references to the strong interest among Chinese companies in investing in African countries, to the fostering 
of buyer-seller relationships, and to differences between perceptions and the reality of sourcing in Africa.

Our analysis acknowledges the different units of analysis adopted in the research: company, buyerseller relationship or (global) value chain. The units of analysis listed in Appendix 1 reflect our interpretations rather than the authors' explications (which in most cases are not provided). It should also be noted that the unit of analysis does not mean the object of the analysis: in many cases the data was collected from one node in the chain even if the focus of the article is on the level of the overall chain. It rather refers to the overall focus, in other words an individual organization (such as a buyer), supply chains, or African countries as a general sourcing context. The focus in the majority of the studies (26) is on supply chains, only one taking a particular buyersupplier relationship (dyad) focus. Moreover, 14 studies concentrate on a single organization, and 16 on the African context. There is a tendency to discuss either the continent or some of its countries as overall contexts of supply, without considering the viewpoints of and/or experiences with local suppliers in detail.

Table III presents the key findings related to each of the themes, as well as the future research avenues we suggest as primary targets for scholars in this area. In the following section we discuss each of the topics in detail.

Table 3. Key findings and future research avenues by theme 


\begin{tabular}{|c|c|c|c|}
\hline Theme & Key findings & $\begin{array}{l}\text { Future research avenues: potential research } \\
\text { questions }\end{array}$ & Suggested theoretical lenses for future study \\
\hline \multirow[t]{3}{*}{$\begin{array}{l}\text { Cultural and } \\
\text { ethical issues }\end{array}$} & $\begin{array}{l}\text { Although community (ubuntu) is generally } \\
\text { acknowledged as a common cultural feature of } \\
\text { African countries, thus far it is recognized in only } \\
\text { a few studies on purchasing. }\end{array}$ & $\begin{array}{l}\text { More focus on the intrinsic features of African } \\
\text { society and business practices: } \\
\text { How does the involvement of foreign buying } \\
\text { firms influence local communities? How can } \\
\text { indigenous issues be built on and used to } \\
\text { benefit future trading? How can } u \text { buntu help or } \\
\text { hinder the development of buyer-supplier } \\
\text { relationships? }\end{array}$ & $\begin{array}{l}\text { Institutional theory (e.g. mix of local and foreign } \\
\text { institutional influences, and their impact on supply } \\
\text { chains on the continent) } \\
\text { Social capital and social network theories (e.g. overlap } \\
\text { of personal/inter-organizational networks, role of } \\
\text { ubuntu, and comparison of ubuntu with the e.g. } \\
\text { Chinese guanxi/Russian blat concepts) } \\
\text { Agency theory (e.g. governance mechanisms of } \\
\text { buyer-supplier relationships in a context with high } \\
\text { corruption) }\end{array}$ \\
\hline & $\begin{array}{l}\text { Significant evidence of corruption and unethical } \\
\text { behavior in purchasing, in particular in public } \\
\text { procurement (most of the evidence is from } \\
\text { Uganda) }\end{array}$ & $\begin{array}{l}\text { More research with a local focus on codes of } \\
\text { conduct: } \\
\text { How should buyers from developed countries } \\
\text { react in situations of supplier corruption and } \\
\text { unethical conduct? }\end{array}$ & $\begin{array}{l}\text { Institutional theory } \\
\text { Change and process theories } \\
\text { (In general, research designs that build on longitudinal } \\
\text { and processual research approaches.) }\end{array}$ \\
\hline & $\begin{array}{l}\text { Most studies provide snapshot views of the } \\
\text { experiences of foreign companies in African } \\
\text { sourcing markets: there is still a need for } \\
\text { longitudinal analyses of the changing supply } \\
\text { context and practices. }\end{array}$ & $\begin{array}{l}\text { Analysis of institutional change in the business } \\
\text { environment, as well as multidisciplinary } \\
\text { studies involving purchasing/SCM, } \\
\text { organizational leadership, and change } \\
\text { management: } \\
\text { How can global standards help to reduce corrupt } \\
\text { behavior in general? } \\
\text { What are the social and cultural challenges } \\
\text { involved in buyer-supplier relationships } \\
\text { between foreign and African countries? }\end{array}$ & \\
\hline $\begin{array}{l}\text { The role of African } \\
\text { suppliers in global } \\
\text { value chains }\end{array}$ & $\begin{array}{l}\text { Some attempts to ensure that small local African } \\
\text { companies become integrated into global value } \\
\text { chains The low cost and poor availability of raw } \\
\text { materials are driving companies to source from } \\
\text { the African continent: in other words country } \\
\text { rather than supplier factors drive entry into global } \\
\text { supply chains }\end{array}$ & $\begin{array}{l}\text { Change the focus from natural to other resources } \\
\text { potentially on offer from African countries and } \\
\text { companies: } \\
\text { What are the key competitive advantages of } \\
\text { African suppliers, as opposed to the continent } \\
\text { as a whole? } \\
\text { What is the value that buyers from developed or } \\
\text { developing (e.g. Chinese) countries can extract } \\
\text { from supply chains in the African continent? }\end{array}$ & $\begin{array}{l}\text { Extended resource-based view (e.g. focus on the rare, } \\
\text { valuable, inimitable and non-substitutable resources } \\
\text { that African suppliers possess or can create to } \\
\text { compete with other low-cost country suppliers) }\end{array}$ \\
\hline \multirow[t]{2}{*}{ Theme } & Key findings & $\begin{array}{l}\text { Future research avenues: potential research } \\
\text { questions }\end{array}$ & Suggested theoretical lenses for future study \\
\hline & $\begin{array}{l}\text { Long lead times, poor-quality products and services, } \\
\text { and inadequate regulations, infrastructure, } \\
\text { technology and skilled personnel prevent African } \\
\text { suppliers from assuming more value-adding roles } \\
\text { in global value chains }\end{array}$ & $\begin{array}{l}\text { Trends in the development of global supply } \\
\text { chains and in the integration of African } \\
\text { suppliers into them: What could be done to } \\
\text { enhance knowledge transfer to African } \\
\text { suppliers and to help them engage in activities } \\
\text { with higher added value in the chains? } \\
\text { More studies on local (multi-actor) supply } \\
\text { networks to make informal and indigenous } \\
\text { processes more visible: How can small } \\
\text { suppliers operating under infrastructural } \\
\text { limitations be efficiently (logistically) } \\
\text { integrated into global networks? }\end{array}$ & $\begin{array}{l}\text { Global value chain theory; Supplier network theories; } \\
\text { International business theories on MNCs } \\
\text { (e.g. potential for African firms to move up the } \\
\text { value-added ladder; FDIs to the African continent, } \\
\text { influence of foreign MNC operations on the African } \\
\text { suppliers) } \\
\text { Contingency theory } \\
\text { (e.g. suitable practices for African operating context) }\end{array}$ \\
\hline Sustainability & $\begin{array}{l}\text { The need to acknowledge local preferences when } \\
\text { engaging in sustainable trading } \\
\text { Differences found in how much foreign } \\
\text { (Chinese/western) buyers push for supplier } \\
\text { certification in Africa }\end{array}$ & $\begin{array}{l}\text { Success factors for codes of conduct in the } \\
\text { African context in terms of who should set the } \\
\text { standards: } \\
\text { What codes of conduct meet both western and } \\
\text { local expectations of good governance? }\end{array}$ & $\begin{array}{l}\text { Stakeholder theory (e.g. power and role of different } \\
\text { stakeholders in developing codes of conduct in Africa) } \\
\text { Institutional theory (e.g. the role of institutional and } \\
\text { stakeholder pressures on sustainability in } \\
\text { multi-continental supply chains) }\end{array}$ \\
\hline $\begin{array}{l}\text { Developing role of the } \\
\text { purchasing profession } \\
\text { and its practices }\end{array}$ & $\begin{array}{l}\text { Functional purchasing practices are still lacking, and } \\
\text { public procurement practices need development } \\
\text { Evidence that formally organized global chains } \\
\text { established by MNEs influence local business } \\
\text { development } \\
\text { Trust building via (interpersonal) networking is } \\
\text { evident and needed }\end{array}$ & $\begin{array}{l}\text { Development of purchasing practices: What can } \\
\text { be done to overcome the inertia and move } \\
\text { towards more transparent and efficient } \\
\text { purchasing practices? } \\
\text { Analysis of interaction behavior and norms in } \\
\text { local and international business relationships: } \\
\text { What are the local norms of interaction and } \\
\text { how do they influence buyer-seller } \\
\text { relationships and value chains? } \\
\text { How do organizations from different } \\
\text { institutional contexts (south-north; } \\
\text { developing-developed) adapt to each other? }\end{array}$ & $\begin{array}{l}\text { Buying behavior theory: } \\
\text { Interorganizational relationship theories; } \\
\text { Organizational learning theories } \\
\text { (e.g. purchasing organization and practices in African } \\
\text { firms; interaction between local and foreign firms) } \\
\text { Information processing theory and absorptive capacity; } \\
\text { Interorganizational relationship theories } \\
\text { (e.g. communication and learning in business } \\
\text { relationships between buyers from developed } \\
\text { countries and African suppliers; performance } \\
\text { outcomes of learning) }\end{array}$ \\
\hline
\end{tabular}

More emphasis on local cultural features and common ethical rules

Overall, socio-cultural aspects and indigenous African cultures have not been extensively covered 
in research on African buyer-supplier relationships. In fact, the procurement literature thus far seems to focus on individualistic and opportunistic behaviors in the form of corruption. Although it is necessary to address this issue, it would be more fruitful to concentrate on the positive aspects of local cultures. Some case studies refer to strong local networks and the value of communities in enhancing cooperation and business (Sartorius and Kirsten 2005; Muller et al. 2012), for instance, and these indigenous features should be given more attention and respect. Similarly, despite the increasing international exposure, there is a lack of research on inter-cultural issues in crossnational relationships between African suppliers and foreign buyers. Moreover, the concept of ubuntu has thus far been ignored in studies on African sourcing. We consider this a primary development area for researchers to tackle, given the extensive coverage of guanxi in studies on sourcing in China (Worm and Michailova 2003; Lu et al. 2008).

Kristal et al. (2011) suggest that researchers focusing on supply chain management should treat culture as an explanatory variable and construct theories that also apply outside the Anglo-Saxon realm. Indeed, theories built up within individualistic cultures may not be compatible with the communal culture of Africa, the implication being that African managers cannot practice what they are taught unless locally relevant management theories are developed (Lutz 2009). Culture also influences foreign buyers. Cultural differences may be a significant hindrance in terms of realizing the benefits of a global sourcing strategy (Kotabe and Mudambi 2009), and cultural distance may be a major barrier to the development of buyer-seller relationships (Lopez-Duarte et al. 2016). There is a need for more research on individual African countries, given that cultural aspects vary depending on language, religion, and the influence of former European colonial hosts, for instance. There is also a need to enhance understanding of interactions on the level of buyer-seller 
relationships. In the case of China, another emerging economy, research on sourcing has only recently incorporated the analysis of relationships and the challenges they involve (see e.g., Salmi 2006; Platts and Song 2010). We therefore recommend that immediate research attention be given to similar socio-political issues in Africa.

Although several of the articles mention noncompliant and unethical behavior in African purchasing, especially in the area of public procurement, the focus is exclusively on the behavior of African buyers and suppliers. Questions of potential unethical conduct (sustainability aside) and corruption are not addressed from the perspectives of Western-African buyer-supplier relations and Western buyers. This is clearly an area in which more research is necessary. What types of misconduct and opportunistic behavior should Western buyers prepare for in their supply chains, and how should they handle them without compromising their own codes of conduct and national legislation? Research built on agency theory and forms of governance could provide fruitful avenues for example by investigating whether process, outcome or social controls (see e.g. Aulakh and Gecturk 2000) are most suited for curbing opportunism in high-corruption environments.

\section{Integrating African suppliers into global value chains}

Overall, the literature is rather limited in justifying the inclusion of African suppliers in global chains, compared to the reasons listed in Nassimbeni (2006) and Quintens et al. (2006) regarding global sourcing in general. Gu (2009) discusses in some depth the rationale behind sourcing from Africa that Chinese enterprises follow, suggesting that they may have been more successful than Western buyers in realizing the benefits of collaboration with African suppliers (encouraged by the supportive policies of the Chinese government). Comparative studies could shed light on 
potential differences in industry- and company-level drivers among buyers from different host countries, showing what Western companies could learn from Chinese enterprises already established in African markets.

In terms of what lies behind the inclusion of African firms in global chains, we see a striking similarity between studies on sourcing from Africa and from both China and India, for example. In the case of China, the focus at the turn of the millennium was on the lower cost of products (Tse et al. 1997; Hathcote and Nam 1999). Weak transportation infrastructure, logistical challenges and poor quality were mentioned as typical challenges in dealing with Chinese suppliers (Murphy et al. 1994; Carter et al. 1997). Schmitz and Knorringa (2000) refer to similar issues in India a bit later. The above-mentioned studies should be of interest to scholars investigating ways of upgrading African suppliers, one option being to assess the main similarities and differences to facilitate supplier development in the African context. Action research could be fruitful in this respect, given previous findings in other developing countries.

There seems to be a need for more research to establish the key sources of competitive advantage among African compared to other low-cost suppliers in global chains. It is evident from Appendix 1 that the level of analysis in most of the studies is rather broad, not discussing African companies as suppliers and how they operate differently from firms in other emerging countries. Approaches such as the (extended) resource-based view (Lavie 2006) could prove useful in investigating how African suppliers can best contribute to global value chains. Suppliers can gain sustained competitive advantage by e.g. a product that is not easily substitutable or if it is difficult for other parties to imitate the buyer-supplier relationship (Steinle and Schiele 2008). Overall, empirical 
supply chain research on the extended resource-based view is rare. The African context provides an interesting opportunity to investigate the formation of sustained competitive advantage in buyer-supplier relationships, while also providing guidance on African suppliers in improving their value chain positioning.

Overall, there appears to be a clear gap in the literature - and a lack of guidance - on the inclusion of African suppliers in global chains and networks from both a social and a logistics perspective. Traditional best practices of supply management that tend to rely on economies of scale (Trautmann et al. 2009) may not be ideal in this context. This provides opportunities for research with a contingency theory focus, investigating the best operational practices in these challenging infrastructural settings. Supply chains including local African producers are also likely to have a larger number of nodes, which may be challenging in terms of maintaining efficiency in logistics (Karjalainen and Moxham 2013).

Tangible barriers to sourcing from Africa involving the infrastructure, product quality, and technology are mentioned in relation to many countries. These findings offer some explanation for the slow progress in integrating Africa into global value chains. As Gereffi and Lee (2012) note, more research is needed to assess the extent to which supply chains are inclusive of or exclusive to suppliers with limited value-adding potential, and to facilitate the development of relevant skills.

\section{Enhancing sustainable supply chains in Africa}

It is clear in several studies (Blowfield and Dolan 2008; Smith 2010; Muller et al. 2012) that the Western view of CSR, sustainability, and codes of conduct is not always the optimal approach in 
local contexts. Empirical research focusing on sustainability should increasingly be based on data from those subjected to the codes of conduct rather than on buyers who are distanced from the local operations. In addition, with regard to integrating African suppliers into global value chains, it is necessary to address recent concerns that such upgrading may bring economic benefits, but not contribute to social upgrading (e.g., jobs and proper labor conditions) (Gereffi and Lee 2012). In order to improve sustainability, stakeholders, such as governments and NGOs, need to be involved more extensively as shown in the study conducted by Huang et al. (2013) on timber imports from Africa to China, as well as in recent studies on sustainable supply chains more generally (Quarshie et al. 2016). Overall, both stakeholder theory as well as institutional theory are suitable lenses for studying sustainable supply chains (Sarkis et al. 2011). Both have been used increasingly to study environmental issues, and would lend themselves well also for social sustainability issues with African suppliers.

\section{Purchasing and professional good practices}

The majority of studies on the purchasing profession included in our review focus on public procurement, implying deficiency, inadequate training and a climate and governance that are conducive to political interference and corruption. In particular, there is scope for multidisciplinary research incorporating change management and organizational leadership aimed at enhancing perceptions of the profession as well as the attitudes of purchasing employees.

Attention should be given to the implementation of good practices in general in African procurement, but whether this should be a subject of academic study or a developmental goal involving the education of professionals is a matter for debate. Although there is an abundance of 
research on identifying good practices for developing countries in the field of international business (Revilla and Saénz 2013), it has not yet permeated the African context. Overall, researchers in the domain of operations management have neglected relationship practices and culture (Hope and Mühlemann 2001).

On the whole, there is very little systematic advice on supply management in African countries, given the local characteristics and challenges. New types of intercultural interaction and modes of purchasing behavior are bound to emerge. As the field progresses, we would expect to see research grounded in contingency theory examining the most suitable ways of managing buyer-supplier relationships and logistics in different African countries. This would require larger-scale qualitative and quantitative studies, with more transparent methods to ensure the representativeness of the findings. The emphasis in some of the articles we reviewed (e.g., Gu 2009 and Huang et al. 2013) on the cumulative presence of Chinese enterprises in Africa points to a need to study these new supply chains operating between two emerging markets, as well as complex global chains that may span several developing and developed countries.

\section{Applying theoretical lenses to research in the African context}

Most of the articles we reviewed make no mention of the theoretical basis used. In some cases we only witnessed 'weak' theories and conceptual frameworks rather than strong, established (organizational) theories rigorously applied to frame the analysis. The work of Adebanjo et al. (2013) is a notable exception: institutional theory was applied to investigate the potential impact of supplier-selection practices on supplier behavior in Nigeria. The authors attribute the stronger effect of normative rather than coercive pressure to the weak role of regulatory agencies in this 
developing-country context. Such studies confirm the need for a strong theoretical basis in future research, and for consideration of the validity of prevailing theories and concepts in the African context.

Indeed, there is a need to investigate the extent to which assumptions underlying widely accepted theories are still valid when the theories are taken out of their original context and applied in analyses of African business. One may well ask whether general theories and practices of supplychain management, or so-called etic theories that can be adopted in different conditions (Revilla and Sáenz 2013), work in Africa. There may be a need to develop local, culture-specific, or emic theories and practices (Revilla and Sáenz 2013) given e.g. the communal cultural orientation in Africa. We have observed here in the area of supply management the same phenomenon to which Jackson (2013) refers in general management: indigenous knowledge should be better integrated into the theorizing and analysis of managerial decision-making. African scholars should be more self-confident in exploring locally relevant research issues in their respective countries - as Asian scholars have also been urged to do (Meyer 2006).

Research reported in leading journals still tends to reflect an Anglo-Saxon perspective (Kristal et al. 2011). Emerging markets could nevertheless enhance overall theory building: the Russian economic transformation into a market economy, for instance, led scholars to discuss the fundamental question of what markets are (Mattsson and Salmi 2013). Similarly, it is essential to acknowledge that the essential assumptions of human nature and behavior which dominate current managerial theories, such as opportunism (transaction cost economics and agency theory) and altruism (stewardship theory), may differ across countries and cultures (see e.g., Chen et al. 2002). 
Africa as an emerging continent offers abundant opportunities for conducting indigenous (contextspecific) as well as comparative (context-embedded) research, both of which are needed in the development of global management (Meyer 2006). This requires research that is conceptually and methodologically robust, rather than focused on empirical descriptions as seems to be the case so far. In Table III, we have provided some initial suggestions of suitable theories to offer a starting point for scholars interested in this context.

\section{Conclusions}

The aim of our systematic review of literature from three major academic databases was to assess the level of current knowledge about sourcing and supply management on the African continent. We identified research gaps and analyzed emerging research themes with a view to suggesting avenues for future investigation. We provide a framework with the four key themes of our analysis, reflecting the distinctive characteristics of Africa as a (sourcing) research context. Our key theoretical contribution is the development of an agenda to guide future research on sourcing and supply (chain) management in and from Africa. An updated research framework positions these research directions in relation to the key themes: 1) African culture and ethics, 2) the role of African countries and suppliers in global value chains, 3) sustainability, and 4) the developing procurement profession and its purchasing practices.

Our study has implications for managers and both African and foreign scholars. On the one hand, we recommend researchers to take a perspective that is broad enough to enhance understanding of the institutional context in which buyer-supplier relations are embedded, as well as the emergence 
of global value chains with African participants. On the other hand, successful interaction with African suppliers requires a better understanding of local, indigenous, country- and continentspecific ways of behaving and doing business. We therefore urge scholars to pay more attention to the applicability - and potential development - of the theoretical concepts employed.

We found no discussion in our reviewed papers on the applicability of the chosen conceptual framework to the African context: in all cases it was implicitly understood as a context-free and etic theory. We therefore urge scholars to pay more attention to the contextual suitability of their theories, and to conduct more strongly theory-grounded research in Africa, and in particular to benefit from the theoretical potential of this (changing) context. Local researchers, in particular, are in a position to develop theories that account for indigenous African features. Many authors were less rigorous in terms of methodological approach, and we therefore call for more care in the design and reporting of future studies.

Although managerial contributions are not the main focus of this research agenda-oriented paper, we believe that our findings on the key drivers, challenges, and opportunities involved in sourcing from Africa may encourage managers to venture into the continent. Knowledge of prominent ethical and corruption issues as identified in previous studies also serves to forewarn buyers working in the area. Africa is quickly assuming more importance in the world economy, and the continent is especially attractive as a sourcing context for global companies. However, this review of scholarly findings reveals that very little is known about sourcing in this context. The African continent may be on the rise, but research in the area of supply chain management is still scattered, and there is an urgent need for more theoretically rich and methodologically rigorous inquiry. 


\section{References}

Acquaah, M. (2012). Social networking relationships, firm-specific managerial experience and firm performance in a transition economy: A comparative analysis of family owned and nonfamily firms. Strategic Management Journal, 33, pp. 1215-1228.

Adebanjo, D., Ojadi, F., Laosirihongthong, T. and Tickle, M. (2013). A case study of supplier selection in developing economies: a perspective on institutional theory and corporate social responsibility. Supply Chain Management: An International Journal, 18, pp. 553-566.

Adeleye, B. C., Annansingh, F. and Nunes, M. B. (2004). Risk management practices in IS outsourcing: an investigation into commercial banks in Nigeria. International Journal of Information Management, 24, pp. 167-180.

Adu-Poku, S., Asamoah, D. and Abor, P. A. (2011). Users' perspective of medical logistics supply chain system in Ghana: The case of Adansi South District Health Directorate. Journal of Medical Marketing: Device, Diagnostic and Pharmaceutical Marketing, 11, pp. 176-190.

Ahimbisibwe, A., Nangoli, S. and Tusiime, W. (2012). Moderating effect of buyer-supplier trust on the relationship between outsourced formal contracts and supplier delivery performance: An empirical study of public sector procurement. International Journal of Business and Social Science, 3, pp. 50-71.

Akenroye, T., Ojo, O. and Aju, O. (2012). Purchasing and supply management practices in corporate Nigeria: An investigation into the financial services industry. International Journal of Business and Social Science, 3, pp. 284-295.

Ambe, I. M. (2014). Difficulty to overcome supply chain challenges faced by vehicle manufacturers in South Africa. Journal of Applied Business Research, 30, pp. 1539-1550.

Angell, L. C. and Klassen, R. D. (1999). Integrating environmental issues into the mainstream: 
an agenda for research in operations management. Journal of Operations Management, 17, pp. 575-598.

Asamoah, D., Yarhands, A. and Assane, S. (2013). Evaluating the effect of logistical drivers on cocoa supply chain in Ghana: A case of Transroyal Ghana limited. International Journal of Business and Social Science, 4, pp. 187-195.

Aulakh, P. and Gencturk, E. (2000). International principal-agent relationships: control, governance and performance. Industrial Marketing Management, 29, pp. 521-538.

Badenhorst, J. A. (1994). Unethical behaviour in procurement: a perspective on causes and solutions. Journal of Business Ethics, 13, pp. 739-745.

Barnes, J. and Kaplinsky, R. (2000a). Globalisation and trade policy reform: Whither the automobile components sector in South Africa? Competition and Change, 4, pp. 211-243.

Barnes, J. and Kaplinsky, R. (2000b). Globalization and the death of the local firm? The automobile components sector in South Africa. Regional studies, 34, pp. 797-812.

Barnes, J. and Morris, M. (2008). Staying alive in the global automotive industry: what can developing economies learn from South Africa about linking into global automotive value chains? The European Journal of Development Research, 20, pp. 31-55.

Baskin, J. (2006). Corporate responsibility in emerging markets. The Journal of Corporate Citizenship, 24, pp. 29-47.

Benner, C. (2006). 'South Africa On-call’: Information technology and labour market restructuring in South African call centres. Regional Studies, 40, pp. 1025-1040.

Blowfield, M. E. and Dolan, C. S. (2008). Stewards of virtue? The ethical dilemma of CSR in African agriculture. Development and Change, 39, pp. 1-23.

Boselie, D., Henson, S. and Weatherspoon, D. (2003). Supermarket procurement practices in 
developing countries: Redefining the roles of the public and private sectors. American Journal of Agricultural Economics, 85, pp. 1155-1161.

Carter, C. R. and Easton, P. L. (2011). Sustainable supply chain management: evolution and future directions. International Journal of Physical Distribution \& Logistics Management, 41, pp. 46-62.

Carter, J. R., Pearson, J. N. and Li, P. (1997). Logistics barriers to international operations: The case of the People's Republic of China. Journal of Business Logistics, 18, pp. 129-145.

Chen, C., Peng, M. and Saparito, P. (2002). Individualism, collectivism, and opportunism: A cultural perspective on transaction cost economics. Journal of Management, 28, pp. 567-583.

Cilliers, W. W. and Nagel, P. J. (1994). Logistics trends in South Africa. International Journal of Physical Distribution and Logistics Management, 24, pp. 4-14.

Cooper, H. M. (1988). Organizing knowledge syntheses: A taxonomy of literature reviews. Knowledge in Society, 1, pp. 104-126.

Cunden, M. and Van Heck, E. (2004). Bargaining power and information technology in AfricanEuropean business relationships: Case of the Dutch flower auctions. European Management Journal, 22, pp. 573-587.

Deng, P. (2012). The internationalization of Chinese firms: A critical review and future research. International Journal of Management Reviews, 14, pp. 408-427

Dixon-Woods, M., Bonas, S., Booth, A., Jones, D., Miller, T., Sutton, A., Shaw, R., Smith, J. and Young, B. (2006). How can systematic reviews incorporate qualitative research? A critical perspective. Qualitative Research, 6, pp. 27-44.

Dos Santos, M. A. O., Svensson, G. and Padin, C. (2013). Indicators of sustainable business practices: Woolworths in South Africa. Supply Chain Management: An International Journal, 
18, pp. 104-108.

Elbadawi, I., Mengistae, T. and Zeufack, A. (2006). Market access, supplier access, and Africa's manufactured exports: A firm level analysis. Journal of International Trade and Economic Development, 15, pp. 493-523.

Fisman, R. and Ghosh, S. (2005). Dynamics of firm-supplier relationships in a less developed economy: Evidence from African manufacturing firms. Southern Economic Journal, 72, pp. 433-442.

Fold, N. (2008). Transnational sourcing practices in Ghana's perennial crop sectors. Journal of Agrarian Change, 8, pp. 94-122.

Gereffi, G. and Lee, J. (2012). Why the world suddenly cares about global supply chains. Journal of Supply Chain Management, 48, pp. 24-32.

Gibbon, P. and Ponte, S. (2005). Trading down: Africa, value chains, and the global economy. Philadelphia, PA: Temple University Press.

Gichure, C. W. (2006). Teaching business ethics in Africa: What ethical orientation? The case of East and Central Africa. Journal of Business Ethics, 63, pp. 39-52.

Golooba-Mutebi, F. (2003). Devolution and outsourcing of municipal services in Kampala city, Uganda: An early assessment. Public Administration and Development, 23, pp. 405-418.

Gruber, V. and Schlegelmilch, B. B. (2015). MNEs' regional headquarters and their CSR agenda in the African context. International Marketing Review, 32, pp. 576-602.

Gu, J. (2009). China's private enterprises in Africa and the implications for African development. European Journal of Development Research, 21, pp. 570-587.

Gupta, V., Hanges, P. J. and Dorfman, P. (2002). Cultural clusters: Methodology and findings. Journal of World Business, 37, pp. 11-15. 
Hathcote, J. and Nam, I. (1999). Advantages of sourcing apparel from China, Taiwan, South Korea, and Mexico. The International Trade Journal, 13, pp. 157-185.

Holtbrügge, D. (2013). Indigenous management research. Management International Review, 53, pp. 1-11.

Hope, C. and Mühlemann, A. (2001). The impact of culture on best-practice production/operations management. International Journal of Management Reviews, 3, pp. 199-217.

Huang, W., Wilkes, A., Sun, X. and Terheggen, A. (2013). Who is importing forest products from Africa to China? An analysis of implications for initiatives to enhance legality and sustainability. Environment, Development and Sustainability, 15, pp. 339-354.

Javalgi, R. R. G., Dixit, A. and Scherer, R. F. (2009). Outsourcing to emerging markets: Theoretical perspectives and policy implications. Journal of International Management, 15, pp. 156-168.

Jackson, T. (2013). Reconstructing the indigenous in African management research. Management International Review, 53, pp. 13-38.

Johnston, K. A., Abader, T., Brey, S. and Stander, A. (2009). Understanding the outsourcing decision in South Africa with regard to ICT. South African Journal of Business Management, 40, pp. 37-47.

Jones, O. and Gatrell, C. (2014). Editorial: The future of writing and reviewing for IJMR. International Journal of Management Reviews, 16, pp. 249-264.

Karjalainen, K. and Moxham, C. (2013). Focus on Fairtrade: Propositions for Integrating Fairtrade and Supply Chain Management Research. Journal of Business Ethics, 116, pp. 267282. 
Karjalainen, K. and Salmi, A. (2013). Continental differences in purchasing strategies and tools. International Business Review, 22, pp. 112-125.

Kaufmann, L., Kreft, S., Ehrgott, M. and Reimann, F. (2012). Rationality in supplier selection decisions: The effect of the buyer's national task environment. Journal of Purchasing and Supply Management, 18, pp. 76-91.

Kauppi, K., Moxham, C. and Bamford, D. (2013). Should we try out for the major leagues? A call for research in sport operations management. International Journal of Operations and Production Management, 33, pp. 1368-1399.

Knight, L., Tate, W.L., Matopoulos, A., Meehan, J. and Salmi, A. (2016). Breaking the mold: Research process innovations in purchasing and supply management. Journal of Purchasing and Supply Management, 22, pp. 239-243.

Kolk, A. and Lenfant, F. (2010). MNC reporting on CSR and conflict in Central Africa. Journal of Business Ethics, 93, pp. 241-255.

Kolk, A., Rivera-Santos, M. and Rufin, C. (2014). Reviewing a decade of research on the “base/bottom of the pyramid” BOP concept. Business \& Society, 53, pp. 338-377.

Kotabe, M. and Mudambi, R. (2009). Global sourcing and value creation: Opportunities and challenges. Journal of International Management, 15, pp. 121-125.

Kowalski, P., Gonzalez, J., Ragoussis, A. and Ugarte, C. (2015). Participation of developing countries in global value chains: Implications for trade and trade-related policies. OECD Trade Policy Papers, No. 179, OECD Publishing, Paris.

Kristal, M., Pagell. M., Yang, C. and Sheu, C. (2011). Are supply chain management theories culturally constrained? An empirical assessment. Operations Management Research, 4, pp. 61-73. 
Kumar, S., Medina, J. and Nelson, M.T. (2009). Is the offshore outsourcing landscape for US manufacturers migrating away from China? Supply Chain Management: An International Journal, 14, pp. 342-348.

Lacity, M. C., Willcocks, L. P. and Craig, A. (2014). South Africa's business process outsourcing services sector: Lessons for Western-based client firms. South African Journal of Business Management, 45, pp. 45-58.

Lavie, D. (2006). The competitive advantage of interconnected firms: An extension of the resource-based view. Academy of Management Review, 31, pp. 638-658.

Lintukangas, K., Smirnova, M., Jumpponen, J., Kouchtch, S., Panfilii, V. and Virolainen, V. (2010). The status of purchasing and supply management in Finland and Russia. Journal of Purchasing and Supply Management, 16, pp. 185-194.

Lopez-Duarte, C., Vidal-Suarez, M.M. and Gonzalez-Diaz, B. (2016). International Business and National Culture: A Literature Review and Research Agenda. International Journal of Management Reviews, 18, pp. 397-416.

Louw, A., Vermeulen, H., Kirsten, J. and Madevu, H. (2007). Securing small farmer participation in supermarket supply chains in South Africa. Development Southern Africa, 24, pp. 539-551.

Lowson, R. (2001). Offshore sourcing: An optimal operational strategy? Business Horizons, 44, pp. 61-66.

Lu, H., Feng, S. and Trienekens, J. H. (2008). Performance in vegetable supply chains: The role of Guanxi networks and buyer-seller relationships. Agribusiness, 24, pp. 253-274.

Lutz, D. W. (2009). African Ubuntu philosophy and global management. Journal of Business Ethics, 84, pp. 313-328. 
Manuj, I. and Mentzer, J. T. (2008). Global supply chain risk management strategies. International Journal of Physical Distribution \& Logistics Management, 38, pp. 192-223.

Martens, B. J., Scheibe, K. P. and Bergey, P. K. (2012). Supply Chains in Sub-Saharan Africa: A Decision Support System for Small-Scale Seed Entrepreneurs. Decision Sciences, 43, pp. 737759.

Mattsson, L. G. and Salmi, A. (2013). The changing role of personal networks during Russian transformation: challenges for Russian management. Journal of Business and Industrial Marketing, 28, pp. 190-200.

Meredith, J. (1993). Theory building through conceptual methods. International Journal of Operations and Production Management, 13, pp. 3-11.

Meyer, K. E. (2006). Asian management research needs more self-confidence. Asia Pacific Journal of Management, 23, pp. 119-137.

Miller, D. (2008). 'Retail renaissance' or company rhetoric: The failed partnership of a South African corporation and local suppliers in Zambia. Labour, Capital and Society, 41, pp. 3455.

Monczka, R. M. and Trent, R. J. (1991). Global sourcing: a development approach. Journal of Supply Chain Management, 27, pp. 2-8.

Moodley, S. (2002). Internet-enabled supply chain integration: prospects and challenges for the South African automotive industry. Development Southern Africa, 19, pp. 659-679.

Moodley, S. and Morris, M. (2004). Does e-commerce fulfil its promise for developing country (South African) garment export producers? Oxford Development Studies, 32, pp. 155-178.

Msimangira, K. A. (2003). Purchasing and supply chain management practices in Botswana. Supply Chain Management: An International Journal, 8, pp. 7-11. 
Muhwezi, M. (2007). When it is necessary or not necessary to start horizontal purchasing collaboration in developing countries: The case for Uganda public procurement units. Journal of Global Business Issues, 1, pp. 195-204.

Muller, C., Vermeulen, W. J. and Glasbergen, P. (2009). Perceptions on the demand side and realities on the supply side: A study of the South African table grape export industry. Sustainable Development, 17, pp. 295-310.

Muller, C., Vermeulen, W. J. and Glasbergen, P. (2012). Pushing or sharing as value-driven strategies for societal change in global supply chains: Two case studies in the British-South African fresh fruit supply chain. Business Strategy and the Environment, 21, pp. 127-140. Müller-Seitz, G. (2012). Leadership in interorganizational networks: A literature review and suggestions for future research. International Journal of Management Reviews, 14, pp. 428443.

Murphy, P. R. and Daley, J. M. (1994). Logistics issues in international sourcing: An exploratory study. International Journal of Purchasing and Materials Management, 30, pp. 21-27.

Narayana, S. A., Pati, R. K. and Vrat, P. (2014). Managerial research on the pharmaceutical supply chain-A critical review and some insights for future directions. Journal of Purchasing and Supply Management, 20, pp. 18-40.

Nassimbeni, G. (2006). International sourcing: Empirical evidence from a sample of Italian firms. International Journal of Production Economics, 103, pp. 694-706.

Nnamdi, O. and Owusu, R. (2014). Africa as a source location: literature review and implications. International Journal of Emerging Markets, 9, pp. 424 - 438.

Nollet, J., Leenders, M. R. and Diorio, M. O. (1994). Supply challenges in Africa. International Journal of Purchasing and Materials Management, 30, pp. 51-56. 
Ntayi, J. M., Ahiauzu, A. and Eya, S. (2011). Psychological climate, catharsis, organizational anomie, psychological wellness and ethical procurement behaviour in Uganda's public sector. Journal of Public Procurement, 11, pp. 1-32.

Okatch, B. A., Mukulu, E. and Oyugi, L. (2011). Constraints to subcontracting arrangements between SMEs and large firms in the motor vehicle industry in Kenya. International Journal of Business and Social Science, 2, pp. 208-223.

Oke, A., Maltz, A. and Christiansen, P. E. (2009). Criteria for sourcing from developing countries. Strategic Outsourcing: An International Journal, 2, pp. 145-164.

Otchere, A. F., Annan, J. and Quansah, E. (2013). Assessing the challenges and implementation of supply chain integration in the cocoa industry: a factor of cocoa farmers in Ashanti region of Ghana. International Journal of Business and Social Sciences, 4, pp. 112-123.

Ouma, S. (2012). Creating and maintaining global connections: Agro-business and the precarious making of fresh-cut markets. Journal of Development Studies, 48, pp. 322-334.

Patton, M. Q. (1990) Qualitative evaluation and research methods. Newbury Park, CA: Sage. Pazirandeh, A. and Norrman, A. (2014). An interrelation model of power and purchasing strategies: A study of vaccine purchase for developing countries. Journal of Purchasing and Supply Management, 20, pp. 41-53.

Phillips, F. (2006). Corporate social responsibility in an African context. The Journal of Corporate Citizenship, 24, pp. 23-27.

Pittaway, L., Robertson, M., Munil, K., Denyer, D. and Neely, A. (2004). Networking and innovation: a systematic review of the evidence. International Journal of Management Reviews, 5/6, pp. 137-168.

Platts, K. W. and Song, N. (2010). Overseas sourcing decisions-the total cost of sourcing from 
China. Supply Chain Management: An International Journal, 15, pp. 320-331.

Pooe, D. R., Mafini, C. and Makhubele, D. T. (2015). Investigating municipal procurement challenges in South Africa: A qualitative study. The International Business \& Economics Research Journal (Online), 14, pp. 67-78.

Quarshie, A., Salmi, A. and Leuschner, R. (2016). Sustainability, CSR and ethics in supply chains: The state of research in SCM and business ethics journals. Journal of Purchasing and Supply Management, 22, pp. 82-97.

Quintens, L., Matthyssens, P. and Faes, W. (2005). Purchasing internationalisation on both sides of the Atlantic. Journal of Purchasing and Supply Management, 11, pp. 57-71.

Quintens, L., Pauwels, P. and Matthyssens, P. (2006). Global purchasing: State of the art and research directions. Journal of Purchasing and Supply Management, 12, pp. 170-181.

Ras, P. J. and Vermeulen, W. J. (2009). Sustainable production and the performance of South African entrepreneurs in a global supply chain. The case of South African table grape producers. Sustainable Development, 17, pp. 325-340.

Revilla, E. and Sáenz, M. J. (2013). Supply chain disruption management: Global convergence vs national specificity. Journal of Business Research, 67, pp. 1123-1135.

Rodrigues, V. S. and Potter, A. (2013). A comparison of FMCG logistics operations in the UK and South Africa. European Business Review, 25, pp. 351-364.

Roxburgh, C., Dorr, N., Leke, A., Tazi-Riffi, A., van Wamelen, A., Lund, S. and ZeinoMahmalat, T. (2010). Lions on the Move. available at: http://www.mckinsey.com/ /media/McKinsey/dotcom/Insights\%20and\%20pubs/MGI/Resear ch/Productivity\%20Competitiveness\%20and\%20Growth/Lions\%20on\%20the\%20move\%20T he\%20progress\%20of\%20African\%20economies/MGI_Lions_on_the_move_african_econom 
ies_full_report.ashx, (access June 26, 2014).

Salmi, A. (2006). Organising international supplier relations: An exploratory study of Western purchasing in China. Journal of Purchasing and Supply Management, 12, pp. 197-208.

Sang, J. K. (2010). Outsourcing in Kenyan universities: An examination of challenges and opportunities. International Journal of Business and Social Science, 1, pp. 204-212.

Sarkis, J., Zhu, Q. and Lai, K. H. (2011). An organizational theoretic review of green supply chain management literature. International Journal of Production Economics, 130, pp. 1-15.

Sartorius, K. and Kirsten, J. (2005). The boundaries of the firm: why do sugar producers outsource sugarcane production? Management Accounting Research, 16, pp. 81-99.

Seuring, S. and Gold, S. (2011). Conducting content-analysis based literature reviews in supply chain management. Supply Chain Management: An International Journal, 17, pp. 544-555.

Seuring, S. and Müller, M. (2008). From a literature review to a conceptual framework for sustainable supply chain management. Journal of Cleaner Production, 16, pp. 1699-1710.

Schmitz, H. and Knorringa, P. (2000). Learning from global buyers. Journal of Development Studies, 37, pp. 177-205.

Schrage, E. J. and Ewing, A. P. (2005). The cocoa industry and child labour. The Journal of Corporate Citizenship, 18, pp. 99-112.

Smith, S. (2010). For love or money? Fairtrade business models in the UK supermarket sector. Journal of Business Ethics, 92, pp. 257-266.

Steinle, C. and Schiele, H. (2008). Limits to global sourcing?: Strategic consequences of dependency on international suppliers: Cluster theory, resource-based view and case studies. Journal of Purchasing and Supply Management, 14, pp. 3-14.

Tranfield, D., Denyer, D. and Smart, P. (2003). Towards a methodology for developing 
evidence-informed management-knowledge by means of systematic review. British Journal of Management, 14, pp. 207-222.

Trautmann, G., Bals, L. and Hartmann, E. (2009). Global sourcing in integrated network structures: The case of hybrid purchasing organizations. Journal of International Management, 15, pp. 194-208.

Tse, D. K., Pan, Y. and Au, K. Y. (1997). How MNCs choose entry modes and form alliances: The China experience. Journal of International Business Studies, 28, pp. 779-805.

Tukamuhabwa, B. R. (2012). Antecedents and consequences of public procurement noncompliance behavior. Journal of Economics and Behavioral Studies, 4, pp. 34-46.

Weatherspoon, D. and Ross, A. (2008). Designing the last mile of the supply chain in Africa: Firm expansion and managerial inferences from a Grocer model of location decisions. International Food and Agribusiness Management Review, 11, pp. 1-16.

West, A. (2014). Ubuntu and business ethics: Problems, perspectives and prospects. Journal of Business Ethics, 121, pp. 47-61.

Wilding, R. and Wagner, B. (2014). Building theory in supply chain management through "systematic reviews" of the literature. Supply Chain Management: An International Journal, 19, pp. 544-555.

Williams, S. and Quinot, G. (2007). Public procurement and corruption: the South African response. South African Law Journal, 124, pp. 339-363.

Woldu, Habte G. (2001). Looking at African value system through cultural dimensions: How do African countries culturally differ among themselves and from the United States? International Conference on African Development Archives, Paper 30, pp. 1-17.

Workneh, A. (2014). International business strategies in Africa: Old supply chains and new 
competitors "Lessons from the Ethiopian-Italian leather trade". International Business

Research, 7, pp. 112-123.

Worm, V. and Michailova, S. (2003) Personal networking in Russia and China: Blat and Guanxi. European Management Journal, 21, pp. 509-519.

Youngdahl, W. E., Ramaswamy, K. and Dash, K. C. (2010). Service offshoring: the evolution of offshore operations. International Journal of Operations and Production Management, 30, pp. $798-820$ 